\title{
Effects of water on P-V-T equation of state of pyrope
}

\author{
Dawei Fan ${ }^{1,2}$, Chang $\mathrm{Lu}^{3}$, Jingui Xu ${ }^{2,4}$, Bingmin Yan ${ }^{1}$, Bin Yang ${ }^{1}$, Jiuhua Chen ${ }^{1,5 *}$ \\ ${ }^{1}$ Center for High Pressure Science and Technology Advanced Research, Changchun 130012, China \\ ${ }^{2}$ Key Laboratory for High Temperature and High Pressure Study of the Earth's Interior, Institute of Geochemistry, \\ Chinese Academy of Sciences, Guiyang 550081, China \\ ${ }^{3}$ Department of Geological Sciences, Jackson School of Geosciences, The University of Texas at Austin, Austin, \\ TX 78712, USA \\ ${ }^{4}$ University of Chinese Academy of Sciences, Beijing 100049, China \\ ${ }^{5}$ Center for the Study of Matter at Extreme Conditions, Department of Mechanical and Materials Engineering, \\ Florida International University, Miami 33199, USA \\ *Corresponding author. E-mail address: chenjh@hpstar.ac.cn
}

\begin{abstract}
High-pressure single-crystal / powder synchrotron X-ray diffraction was carried out on a hydrous pure magnesium pyrope $\left(\mathrm{Mg}_{3} \mathrm{Al}_{2} \mathrm{Si}_{3} \mathrm{O}_{12}\right)$ containing 900 ppmw $\mathrm{H}_{2} \mathrm{O}$, synthesized at $4.0 \mathrm{GPa}$ and $1300 \mathrm{~K}$. The pressure-volume $(P-V)$ single-crystal data from room pressure to $9.81 \mathrm{GPa}$ at ambient temperature were fitted by a third-order Birch-Murnaghan equation of state (BM-EoS) yielding a unit-cell volume of $V_{0}=1505.14 \pm 0.38 \AA^{3}$, an isothermal bulk modulus of $K_{0}=160 \pm 3 \mathrm{GPa}$ and its pressure derivative $K_{0}^{\prime}=5.2 \pm 0.4$. When fixing $K_{0}^{\prime}=4.0$, the data yielded $V_{0}=1504.58 \pm 0.32 \AA^{3}$ and $K_{0}=166 \pm 2 \mathrm{GPa}$. The pressure-volume-temperature $(P-V-T)$ EoS of the synthetic hydrous pyrope was also measured at temperatures up to $900 \mathrm{~K}$ and pressures up to $16.75 \mathrm{GPa}$, using a diamond anvil cell in conjunction with in situ synchrotron angle-dispersive powder X-ray diffraction. The $P-V$ data at room temperature and in a pressure range of $0.0001-14.81 \mathrm{GPa}$ were then analyzed by a third-order BM-EoS and yielded $V_{0}=1505.35 \pm 0.25 \AA^{3}, K_{0}=161 \pm 2 \mathrm{GPa}, K_{0}^{\prime}=5.0 \pm 0.3$. With $K_{0}^{\prime}$ fixed to 4.0, we also obtained $V_{0}=1505.04 \pm 0.29 \AA^{3}$ and $K_{0}=167 \pm 1 \mathrm{GPa}$. Consequently, we fitted the $P-V-T$ data with the high-temperature third-order BM-EoS approach and obtained the thermoelastic parameters of $V_{0}=1505.4 \pm 0.3 \AA^{3}, K_{0}=162 \pm 1 \mathrm{GPa}, K_{0}^{\prime}=4.9 \pm 0.2$, the temperature derivative of the bulk modulus $\left(\partial K_{0} / \partial T\right)_{P}=-0.018 \pm 0.004 \mathrm{GPaK}^{-1}$, and the thermal expansion
\end{abstract}


coefficient at ambient conditions $\alpha_{0}=(3.2 \pm 0.1) \times 10^{-5} \mathrm{~K}^{-1}$. These properties were consistent with the thermal pressure EoS analysis. These new results on hydrous pyrope were also compared with previous studies of anhydrous pyrope. The main effect of hydration on pyrope is to decrease $K_{0}$ and increase $K_{0}^{\prime}$ by increasing the vacancies or unoccupied volume in the structure. The entire dataset enabled us to examine the thermoelastic properties of important mantle garnets and this data has further applications for modeling the P-T conditions in the upper mantle of the Earth's interior using deep mineral assemblages.

Keywords: Hydrous pyrope; Equation of state; High temperature and pressure; X-ray diffraction; Diamond anvil cell

\section{Introduction}

Silicate garnets are nesosilicates with the general formula $\mathrm{X}_{3} \mathrm{Y}_{2}\left(\mathrm{SiO}_{4}\right)_{3}$, where the eight-coordinated dodecahedral $\mathrm{X}$ sites are usually occupied by divalent cations (typically $\mathrm{Mg}, \mathrm{Fe}$, $\mathrm{Mn}$, or $\mathrm{Ca}$ ) and the six-coordinated octahedral $\mathrm{Y}$ sites by trivalent cations (typically $\mathrm{Al}, \mathrm{Fe}$, or $\mathrm{Cr}$ ). These octahedral/tetrahedral sites form a three-dimensional corner-sharing network which defines interstitial dodecahedral divalent metal sites with eight-fold coordination (Smyth et al. 2000). Garnets are widespread minerals in the upper mantle and transition zone of Earth, comprising of up to $40 \%$ of the pyrolite composition volume and up to $70 \%$ of the eclogitic composition (Akaogi and Akimoto 1977; Anderson and Bass 1984; Irifune and Ringwood 1987; Ita and Stixrude 1992; Dymshits et al., 2014). Garnets are also important components of the subducted oceanic crust (Irifune and Ringwood 1993; Karato et al. 1995) as stable phases in a wide range of pressures and temperatures, and play a fundamental role in many high-pressure and high-temperature petrologic processes (Deer et al. 1992; Pavese et al. 2001). As the principal mineral end member of the garnet group, pyrope $\left(\mathrm{Mg}_{3} \mathrm{Al}_{2} \mathrm{Si}_{3} \mathrm{O}_{12}\right)$ is widely accepted as playing an important role in understanding the properties of the upper mantle and transition zone (Withers et al. 1998; Mookherjee and Karato 2010). Garnet lherzolite models of the upper mantle can contain a pyrope volume about 15\% (Gwanmesia et al. 2006). Pyrope forms a complete solid solution with $\mathrm{MgSiO}_{3}$-majorite (Gasparik 2000), another garnet found in the upper mantle and transition zone of the Earth. Natural garnets from eclogite xenoliths are usually pyrope-rich (Lu and Keppler 
1997). Therefore, accurate knowledge of the thermoelastic properties of pyrope is directly relevant for deducing appropriate compositional models, seismic tomographic images, and the velocity and density profiles of the Earth's interior (e.g. Duffy and Anderson 1989; Flanagan and Shearer 1999; Weidner and Wang 2000).

The nominally anhydrous mineral phases in the Earth's upper mantle and transition zone (410-660 km depth) may serve as a large internal reservoir of water which has profound implications for Earth's evolution as a water planet (Ohtani 2005; Beran and Libowitzky 2006; Tenner et al. 2009). Water plays important roles in the phase transformation kinetics in the Earth's interior, which affects the mantle dynamics (e.g., Kubo et al. 1998). Trace amounts of dissolved hydrogen defects in nominally anhydrous mantle phases influence the physical properties of mantle materials, such as rheology (e.g., Karato 2006), elasticity (e.g., Jacobsen 2006), electrical conductivity (e.g., Karato 1990; Huang et al. 2005), and shear strength (e.g., Chen et al. 1998; Mei and Kohlstedt 2000; Jung and Karato 2001; Kavner 2003). Much effort has been made estimating the water storage capacity of nominally anhydrous mineral phases to determine factors controlling water incorporation into the structure (e.g., Mackwell and Kohlstedt 1990; Rossman and Aines 1991; Kohlstedt et al. 1996; Rossman 1996; Lu and Keppler 1997; Withers et al. 1998; Smyth et al. 2003, 2007; Skogby 2006; Mookherjee and Karato 2010; Tenner et al. 2012). In the context of water storage at high pressures, garnet is a particularly important phase because grossular $\left(\mathrm{Ca}_{3} \mathrm{Al}_{2} \mathrm{Si}_{3} \mathrm{O}_{12}\right)$ is known to be capable of dissolving up to 20.80 wt.\% $\mathrm{H}_{2} \mathrm{O}$ (Passaglia and Rinaldi 1984; O’Neill et al. 1993) and significant water content has been found in pyropic garnet from xenoliths (Bell and Rossman 1992). Water content in garnet also can be used to place constraints on water fugacities (Aines and Rossman 1984). Trace element zoning in garnet may be used to investigate the P-T paths in metamorphic rocks (Hickmott et al. 1987; Hickmott 1989). Hydrogen zonation in garnet may be an important source of information about the metamorphic processes that occur during crystal growth (Hickmott 1989). Since garnet increases in abundance from about $5 \%$ volume at a $150 \mathrm{~km}$ depth to around $30 \%$ at a $650 \mathrm{~km}$ depth (Ringwood 1991), it is important to know whether this phase can dissolve large amounts of water throughout its compositional and P-T stability range. Previous studies have revealed that hydroxyl occurrence in nominally anhydrous mantle phases is closely related to cation vacancy defects (e.g., Stalder et al. 2005; Skogby 2006). Moreover, water may be incorporated in garnets as $\mathrm{OH}^{-}$defects associated with 
charge balancing or oxidation-reduction reactions, or it may substitute $\mathrm{Si}$ in the hydrogarnet substitution (Lu and Keppler 1997; Withers et al. 1998; Mookherjee and Karato 2010). Therefore, the hydrous component in garnet has important geological implications for the Earth's mantle, and it is critical to understand the state of water and its role in the structure of garnets in the Earth's interior.

To date, the elasticity of pyrope has been extensively studied using both multi-anvil apparatus and the diamond anvil cell (e.g., Hazen and Finger 1978; Sato et al. 1978; Levien et al. 1979; Leitner et al. 1980; Leger et al. 1990; Conrad et al. 1999; Zhang et al. 1998; Chen et al. 1999; Wang and Ji 2001; Sinogeikin and Bass 2000, 2002; Li et al. 2011). Up to now, most of the pyrope studies have been limited to either high pressure and room temperature or ambient pressure and high temperature, however, there have been few studies that focus on the thermoelastic properties of pyrope (Bonczar and Graham 1977; Wang et al. 1998; Sinogeikin and Bass 2002; Gwanmesia et al. 2006; Zou et al. 2012; Lu et al. 2013; Du et al. 2015). Furthermore, to our knowledge, there are no reports about the thermoelasticity of hydrous pyrope at simultaneously high pressure and high temperature, which hinders the accurate determination of appropriate compositional models and density profiles of the Earth's upper mantle.

Here, we investigated the pressure-volume-temperature $(P-V-T)$ relations of a synthetic hydrous pyrope at high pressure and high temperature up to $17 \mathrm{GPa}$ and $900 \mathrm{~K}$, using a diamond anvil cell combined with in situ synchrotron radiation angle-dispersive X-ray diffraction. The thermoelastic properties of the hydrous pyrope were obtained by fitting the present $P-V-T$ data to the high-temperature Birch-Murnaghan (HTBM) EoS and thermal pressure EoS. We also discuss our results with respect to previous reports of the thermoelastic properties of anhydrous pyrope, and evaluate the high pressure-temperature and hydrogen effects on pyrope to aid the current understanding of Earth's deep upper-mantle mineralogical models.

\section{Sample and Experimental methods}

\subsection{Sample}

The synthesis of hydrous pyrope was carried out using a multi-anvil pressure apparatus (YJ-3000T), at the Institute of Geochemistry, Chinese Academy of Sciences, Guiyang, China. 
Details of this experimental set-up are described elsewhere by Xie et al. (1993). The pressurization system of this press consisted of six WC anvils, with their tips truncated to $23.5 \times 23.5 \mathrm{~mm}^{2}$, which were simultaneously pushed by six hydraulic rams to generate high pressure in the experimental assembly (Fan et al. 2013). The pressure in the sample chamber was calibrated using a quartz-coesite phase transition and the high-pressure melting curve of copper, with a pressure measurement error margin of less than $1.5 \%$. The temperature in the sample chamber was measured using a Pt-Pt ${ }_{90} \mathrm{Rh}_{10}$ thermocouple, with an uncertainty value less than $5 \mathrm{~K}$ (Xie et al. 1993, 2002). The starting materials used in the synthesizing experiments were stoichiometric amounts of high purity magnesium oxide $(\mathrm{MgO})$, aluminum oxide $\left(\mathrm{Al}_{2} \mathrm{O}_{3}\right)$ and silica $\left(\mathrm{SiO}_{2}\right)$. The mixture was then melted at $1700 \mathrm{~K}$ which produced a homogeneous glass after quenching. The homogeneous glass was crushed and ground into a fine powder in acetone and then encapsulated in platinum capsules with $10 \mathrm{wt} . \%$ of deionised water. The synthesis was carried out at $4.0 \mathrm{GPa}$ and $1300 \mathrm{~K}$ with a run duration of $48 \mathrm{~h}$, and perfectly clear and inclusion-free single crystals of pyrope were picked from the charge. The ambient X-ray diffraction data were collected using a D/Max-2200 X-ray diffractometer with graphite crystal monochromator and $\mathrm{Cu} \mathrm{K} \alpha$ radiation. The ambient powder X-ray spectrum of pyrope was indexed according to the standard spectra (JCPDS 87-1093), confirming that the structure of the synthetic pyrope was cubic, and belonged to the $I a \overline{3} d$ space group. The electron probe microanalysis further confirmed that the synthetic sample was a single phase with the composition as follows (in wt\%): $\mathrm{MgO}, 29.9(3) ; \mathrm{Al}_{2} \mathrm{O}_{3}, 24.9(2) ; \mathrm{SiO}_{2}$, 44.7(2), which can be also written in term of formula unit as $\mathrm{Mg}_{3.01} \mathrm{Al}_{2.00} \mathrm{Si}_{3.01} \mathrm{O}_{12}$.

Several crystals were mounted individually in epoxy resin so that doubly-polished crystal slabs could be prepared. After polishing, the crystal slabs were extracted from the resin and cleaned using $\mathrm{CCl}_{4}$. An electronic micrometer with a $1 \mu \mathrm{m}$ precision was used to measure the sample thickness, which ranged between 300 and 500 $\mu \mathrm{m}$. A Nicolet 5700 FTIR spectrometer coupled with a microscope was used to analyze the $\mathrm{OH}$ contents of X-ray-oriented, faceted single crystals using a $\mathrm{KBr}$ beam-splitter and a liquid-nitrogen cooled MCT-A detector. Measurements were performed through optically clean, inclusion-free, and crack-free areas under a continuous dry air flush. Where samples were large enough, we employed a focused $100 \mu \mathrm{m}$ spot size on the crystal surface through redundant aperturing. Smaller apertures were used to analyze areas down to $40 \times$ $40 \mu \mathrm{m}$. Our synthesized pyropes have an asymmetric peak in the absorption spectrum centered at 
$3630 \mathrm{~cm}^{-1}$ (Fig. 1), which corresponds exactly to those in the OH spectra of synthetic pyropes of previous studies (Geigei et al., 1991; Withers et al., 1998). The water contents were computed from integrated absorbances using the calibration of Bell et al. (1995) for pyrope, which showed that the water content of this hydrous pyrope sample was about 900 ppmw.

\subsection{Room temperature and high pressure single-crystal $X$-ray diffraction experiment}

Before loading into the diamond anvil cell, the pyrope crystal was examined in air. The refined unit-cell parameters constrained to cubic symmetry are reported in Table 1. The in situ room-temperature and high-pressure synchrotron single-crystal X-ray diffraction experiments were carried out at the BL15U1 beamline using angle-dispersive diffraction with diamond-anvil cells at the Shanghai Synchrotron Radiation Facility (SSRF). A symmetric-type diamond anvil cell equipped with $500 \mu \mathrm{m}$ diamond culets was used for pressure generation. A gasket made of stainless steel foil (type T301) with pre-indented thickness of $\sim 55 \mu \mathrm{m}$ and a center hole of $200 \mu \mathrm{m}$ in diameter served as the sample chamber. The 4:1 methanol-ethanol mixture was used as a pressure transmitting medium, which is hydrostatic up to $10 \mathrm{GPa}$ as demonstrated by Piermarini et al. (1973) and Angel et al. (2007). A ruby chip was loaded as a pressure calibrant together with the hydrous pyrope sample (about $50 \times 50 \times 25 \mu \mathrm{m}$ ) in the sample chamber. Ruby fluorescence spectra were collected before and after each collection of X-ray diffraction data, and the positions of the R1 and R2 peaks were determined by fitting them with Lorentzian functions. The pressure was calculated from the fitted R1 and R2 peak positions using the method of Mao et al. (1978). Diffraction images were collected using MAR-165 charge coupled device (CCD) detector, placed at a distance of approximately $180 \mathrm{~mm}$ to the sample. The detector geometry parameters were calibrated using a $\mathrm{CeO}_{2}$ diffraction standard. The X-ray beam was monochromatized to a wavelength of $0.6199 \AA$ and focused down to $2 \times 3 \mu \mathrm{m}^{2}$ area. Diffraction data were collected while the diamond anvil cell rotated around the vertical axis of the instrument ( $\omega$-axis) from -12 to $+12^{\circ}$, with a typical exposure time of $0.5 \mathrm{~s} / \mathrm{deg}$. Diffraction images were analyzed using the GSE_ADA/RSV software package (Dera et al. 2013). Then, the unit-cell parameters of hydrous pyrope were calculated by a least squares technique using Unitcell software (Holland and Redfern 1997). Each diffraction pattern has at least 30 good single crystal diffraction spots. Except the single crystal diffraction spots of diamond, all the other single crystal diffraction spots could be successfully indexed using the cubic symmetry of pyrope. In the calculation, at least 11 sample 
diffraction spots were used to refine the unit-cell parameters: (400), (420), (332), (422), (431), (521), (611), (620), (444), (640), and (642).

\subsection{High-temperature and high-pressure powder $X$-ray diffraction experiment}

High-temperature and high-pressure experiments were carried out by using a modified Merrill-Bassett type diamond-anvil cell. The culet-size of the diamonds, sample chamber of the gaskets and the pressure transmitting medium were the same as those in the single crystal diffraction experiment. The hydrous pyrope powders were slightly pressed between two opposing diamond anvils to form an approximately $25 \mu \mathrm{m}$ thick disk, and a piece of the sample about 100 $\mu \mathrm{m}$ in diameter was loaded into the sample chamber. The cell pressure was determined using the equation of state of gold (pressure marker) as proposed by Fei et al. (2007). Heating was conducted using a resistance-heating system, and the temperature was measured using a $\mathrm{Pt}_{90} \mathrm{Rh}_{10}-\mathrm{Pt}_{100}$ thermocouple attached to the pavilion of the diamond anvil. We first compressed the sample up to $10 \mathrm{GPa}$ and then increased the temperature up to $900 \mathrm{~K}$. Heating was maintained at $900 \mathrm{~K}$ for about 15 minutes in order to minimize the effect of any stress that could develop during cold compression. Following this, the temperature was lowered down to $300 \mathrm{~K}$ in $200 \mathrm{~K}$ steps. At each P-T condition, an X-ray diffraction pattern was collected after the experiment temperature was maintained for $\sim 600 \mathrm{~s}$. The typical exposure time for collecting the diffraction patterns of the sample and the pressure marker was $600 \mathrm{~s}$. Details of the experimental setup and cell assembly are described in Fan et al. (2010).

In situ high temperature and high pressure powder X-ray diffraction experiments were conducted at the 4W2 beamline of the Beijing Synchrotron Radiation Facility (BSRF). An image plate detector (MAR-345) was used to collect diffraction patterns. The wavelength of the monochromatic X-ray beam was $0.6199 \AA$ and calibrated by scanning through the Mo metal $K$-absorption edge. The X-ray beam was focused to a beam size of $20 \times 30 \mu \mathrm{m}^{2}$ full-width at half maximum (FWHM) by a pair of Kirkpatrick-Baez mirrors. The tilting and rotation of the detector relative to the incident $\mathrm{X}$-ray beam was calibrated using cerium dioxide $\left(\mathrm{CeO}_{2}\right)$ powder as the $\mathrm{X}$-ray diffraction standard. The sample-detector distance was calculated from the powder $\mathrm{CeO}_{2}$ diffraction pattern at ambient conditions. The collected diffraction patterns were integrated to generate the conventional one-dimensional diffraction profiles using Fit2D (Hammersley et al. 1996). Figure 2 shows a typical fitting of the full X-ray diffraction pattern of hydrous pyrope at 
10.79 GPa and $900 \mathrm{~K}$. Analyses of all the patterns were carried out using the full profile-fitting technique implemented in the EXPGUI/GSAS software package (Larson and Von Dreele 2000; Toby 2001). The refinement of the peak positions and extraction of the cell parameters were achieved by reducing full diffraction patterns following the Le Bail method (Le Bail et al. 1988). Precision of the volume determination for hydrous pyrope was estimated from the full spectrum fitting (Le Bail refinement) of X-ray diffraction profiles.

\section{Results and Discussion}

The unit-cell parameters of hydrous pyrope refined from single-crystal and powder X-ray diffraction are summarized in Table 1 and 2, respectively. The room temperature and high pressure single-crystal X-ray diffraction data were fitted to the third-order BM-EoS to derive bulk modulus $\left(K_{0}\right)$ and its pressure derivative $\left(K_{0}^{\prime}\right)$ of hydrous pyrope. For the high temperature and high pressure powder X-ray diffracton data, first we fitted the compression $P-V$ data at the $300 \mathrm{~K}$ isotherm to the BM-EoS for comparison, and then applied the high-temperature BM-EoS and thermal pressure EoS approach to derive the thermoelastic parameters from the measured $P-V-T$ data.

\subsection{Room-Temperature Birch-Murnaghan equation of state (BM-EoS)}

The pressure-volume $(P-V)$ data from the single-crystal (Table 1) and powder sample (Table 2) were fitted to a third order BM-EoS:

$$
P=(3 / 2) K_{0}\left[\left(V_{0} / V\right)^{7 / 3}-\left(V_{0} / V\right)^{5 / 3}\right] \times\left\{1+(3 / 4)\left(K_{0}^{\prime}-4\right)\left[\left(V_{0} / V\right)^{2 / 3}-1\right]\right\}
$$

where $V_{0}, K_{0}$, and $K_{0}^{\prime}$ are the unit-cell volume, isothermal bulk modulus and its pressure derivative at ambient conditions, respectively. The fitting without any constraints yielded $V_{0}=1505.14 \pm 0.38$ $\AA^{3}, K_{0}=160 \pm 3 \mathrm{GPa}, K_{0}^{\prime}=5.2 \pm 0.4$ for the single-crystal sample and $V_{0}=1505.35 \pm 0.25 \AA^{3}, K_{0}=$ $161 \pm 2 \mathrm{GPa}, K_{0}^{\prime}=5.0 \pm 0.3$ for the powder sample. With fixed $K_{0}^{\prime}$ at 4 (i.e. the second order BM-EoS), the fitting yielded $V_{0}=1504.58 \pm 0.32 \AA^{3}$ and $K_{0}=166 \pm 2 \mathrm{GPa}$ for the single-crystal and $V_{0}=1505.04 \pm 0.29 \AA^{3}$ and $K_{0}=167 \pm 1 \mathrm{GPa}$ for the powder. The single-crystal and powder data show excellent agreement with each other. Fitting the combined data yielded: $V_{0}=1505.02 \pm 0.23$ $\AA^{3}, K_{0}=161 \pm 2 \mathrm{GPa}, K_{0}^{\prime}=5.2 \pm 0.3$ (without any constraints) and $V_{0}=1504.33 \pm 0.31 \AA^{3}$, and $K_{0}=$ $167 \pm 1 \mathrm{GPa}$ (with fixed $K_{0}^{\prime}=4$ ). Figure 3 shows the volume compression $\left(V / V_{0}\right)$ of hydrous pyrope 
as a function of pressure $(P)$ and the derived equation of state from the combined data (without any constraints).

The second order BM-EoS yielded a significant larger $K_{0}$ than the third order BM-EoS. Figure 4 shows the volume Eulerian finite strain $\left(f_{E}=\left[\left(V_{0} / V\right)^{2 / 3}-1\right]\right)$ versus the "normalized pressure" $\left(F_{E}=\right.$ P/[3 $\left.\left.f_{E}\left(2 f_{E}+1\right)^{5 / 2}\right]\right)$ plot (i.e. $F_{E}-f_{E}$ plot, (Angel 2000)) of hydrous pyrope in this study. The weighted linear regression through the data points yielded the hydrous pyrope intercept value, $F_{E}(0)=161 \pm 2 \mathrm{GPa}$, which shows excellent agreement with the isothermal bulk modulus obtained by the third-order BM-EoS $(161 \pm 2 \mathrm{GPa})$. Furthermore, it is clear from Figure 4 that the normalized pressure as a function of the Eulerian strain at $300 \mathrm{~K}$ has a positive slope, which is consistent with a value of $K_{0}^{\prime}$ slightly larger than 4 (Angel 2000) shows that the third-order BM-EoS is a reasonable description of the $P-V$ data in this study.

We used a methanol-ethanol mixture with a ratio of $4: 1$ for the pressure medium in this study. This medium solidifies at a pressure above $10 \mathrm{GPa}$, and therefore the hydrostatic pressure environment in the sample chamber may be influenced (Piermarini et al. 1973; Angel et al. 2007). However, the sample chamber in this study was heated up to $900 \mathrm{~K}$ at pressures higher than 10 GPa for the relaxation of the deviatoric stress. The effect of deviatoric stress on the unit-cell volume measurements should be minimal, and this is confirmed by fitting the experimental data under hydrostatic conditions (below $10 \mathrm{GPa}$ ) which yields a very similar result $\left(K_{0}=162 \pm 3 \mathrm{GPa}\right.$, $\left.K_{0}^{\prime}=4.9 \pm 0.5\right)$ to the whole pressure range fitting.

\subsection{High-Temperature Birch-Murnaghan equation of state}

The $P$ - $V-T$ data (Table 2) from powder X-ray diffraction experiments were used to determine the thermoelastic properties of hydrous pyrope up to $\sim 17 \mathrm{GPa}$ and $900 \mathrm{~K}$. The high temperature third order BM-EoS was applied to our high pressure and high temperature data in the following form:

$$
P=(3 / 2) K_{T O}\left[\left(V_{T O} / V\right)^{7 / 3}-\left(V_{T O} / V\right)^{5 / 3}\right] \times\left\{1+(3 / 4)\left(K_{T O}^{\prime}-4\right)\left[\left(V_{T O} / V\right)^{2 / 3}-1\right]\right\}
$$

In this equation, the thermal dependences of the zero-pressure volume $\left(V_{T 0}\right)$ and the bulk modulus $\left(K_{T 0}\right)$ at different temperatures are expressed using the following equations:

$$
\begin{gathered}
V_{T 0}=V_{0} \exp \int_{300}^{T} \alpha_{\mathrm{T}} d T \\
K_{T 0}=K_{0}+\left(\partial K_{\partial} \partial T\right)_{P} \times(\mathrm{T}-300)
\end{gathered}
$$


where $\alpha_{T}$ is the thermal expansion at ambient pressure and $\left(\partial K_{0} / \partial T\right)_{P}$ is the temperature derivative of $K_{0}$ at constant $\mathrm{P}$.

The thermoelastic parameters $\alpha_{0},\left(\partial K_{0} \partial T\right)_{P}$, and $K_{0}$ of the hydrous pyrope obtained in this study are showed in Table 4 and Figure 5. Fitting our $P-V$-T data to the high temperature BM EoS yielded $V_{0}=1505.38 \pm 0.27 \AA^{3}, K_{0}=162 \pm 1 \mathrm{GPa}, K_{0}^{\prime}=4.9 \pm 0.2,\left(\partial K_{0} / \partial T\right)_{P}=-0.018 \pm 0.004 \mathrm{GPaK}^{-1}$ and $\alpha_{0}=(3.2 \pm 0.1) \times 10^{-5} \mathrm{~K}^{-1}$. With $K_{0}^{\prime}$ fixed to 4.0 , we also obtained $V_{0}=1505.22 \pm 0.28 \AA^{3}, K_{0}=$ $168 \pm 1 \mathrm{GPa},\left(\partial K_{0} / \partial T\right)_{P}=-0.017 \pm 0.005 \mathrm{GPaK}^{-1}$ and $\alpha_{0}=(3.06 \pm 0.09) \times 10^{-5} \mathrm{~K}^{-1}$ for hydrous pyrope. The $K_{0}$ values determined here are consistent with those derived from our $P-V$ data fitting at 300 $\mathrm{K}$ within accepted uncertainties. We also calculated the temperature derivative of the bulk modulus extracted from each isotherm, and obtained $\left(\partial K_{0} \partial T\right)_{P}=-0.018 \pm 0.005 \mathrm{GPa} \mathrm{K}^{-1}$ for hydrous pyrope, which is very consistent with the results from the whole set of $P-V-T$ data available in this study $\left(\left(\partial K_{0} / \partial T\right)_{P}=-0.018 \pm 0.004 \mathrm{GPa} \mathrm{K}^{-1}\right)$ within their uncertainties.

Likewise, fitting the $P-V-T$ data at pressures below $\sim 10 \mathrm{GPa}$ to the high temperature BM-EoS yielded $V_{0}=1505.33 \pm 0.31 \AA^{3}, K_{0}=163 \pm 2 \mathrm{GPa}, K_{0}^{\prime}=5.1 \pm 0.4,\left(\partial K_{0} / \partial T\right)_{P}=-0.020 \pm 0.006 \mathrm{GPaK}^{-1}$ and $\alpha_{0}=(3.3 \pm 0.2) \times 10^{-5} \mathrm{~K}^{-1}$. These values are very consistent with the results of fitting all the $P-V-T$ data that lead to $V_{0}=1505.38 \pm 0.27 \AA^{3}, K_{0}=162 \pm 1 \mathrm{GPa}, K_{0}^{\prime}=4.9 \pm 0.2,\left(\partial K_{0} / \partial T\right)_{P}=$ $-0.018 \pm 0.004 \mathrm{GPaK}^{-1}$ and $\alpha_{0}=(3.2 \pm 0.1) \times 10^{-5} \mathrm{~K}^{-1}$ within their uncertainties.

\subsection{Thermal pressure equation of state}

We also analyzed the $P-V-T$ data using a thermal pressure approach (e.g., Anderson 1995; Jackson and Rigden 1996). The thermal pressure $\left(\Delta P_{t h}\right)$ was obtained by subtracting the pressure at volume $(V)$ and at room temperature (derived from Eq. (1)) from the pressure measured at the same $V$ and at temperature $(T)$

$$
\Delta P_{\mathrm{th}}=P(V, T)-P(V, 300)=\left[\alpha K_{T}+\left(\frac{\partial K_{T}}{\partial T}\right)_{V} \ln \left(\frac{V_{0}}{V}\right)\right] \times(T-300)
$$

Figs. 6 and 7 show the thermal pressure of hydrous pyrope against temperature and the unit-cell volume, respectively. The show that the thermal pressure of hydrous pyrope varies linearly with temperature and is almost independent of volume. A fit of the data in this study yielded $K_{0}=160 \pm 2$ $\mathrm{GPa}, K_{0}^{\prime}=4.8 \pm 0.4$, and $\alpha_{0}=(2.9 \pm 0.2) \times 10^{-5} \mathrm{~K}^{-1}$, which is reasonably consistent with those derived by HTBM EoS fitting (Table 4). Within the uncertainty of the fit, the $\left(\partial K_{T} / \partial T\right)_{V}$ value is roughly zero, indicating that the thermal pressure is independent of volume. Wang et al. (1998) also found 
that the thermal pressure in garnet shows linear variation with $\mathrm{T}$ up to $1200 \mathrm{~K}$ independent of compression $\left(V / V_{0}\right)$, concluding that the $\left(\partial K_{T} / \partial T\right)_{V}$ is very close to zero. The same conclusion has been drawn for many other silicate minerals, such as olivine (Guyot et al. 1996), $\mathrm{CaSiO}_{3}$ perovskite (Wang et al. 1996) and ringwoodite (Nishihara et al. 2004). By using the thermodynamic relation: $\left(\partial K_{T} / \partial T\right)_{P}=\left(\partial K_{T} / \partial T\right)_{V}-\alpha K_{T} K_{T}^{\prime}$, we obtained $\left(\partial K_{0} \partial T\right)_{P}=-0.021(3)$ $\mathrm{GPaK}^{-1}$ which is in good agreement with current analysis using HTBM EoS (Table 4).

\subsection{Comparison with previous studies of anhydrous pyrope}

Our hydrous pyrope results compared with previous studies for anhydrous pyrope are also shown in Table 3. Numerous studies on elastic properties of anhydrous pyrope have been investigated by some authors. Table 3 summarizes the $K_{0}$ and $K_{0}^{\prime}$ for anhydrous pyrope determined by various experimental techniques, including X-ray diffraction, ultrasonic interferometry and Brillouin scattering spectroscopy (Hazen and Finger 1978; Sato et al. 1978; Levien et al. 1979; Leitner et al. 1980; Leger et al. 1990; Conrad et al. 1999; Zhang et al. 1998; Chen et al. 1999; Wang and Ji 2001; Sinogeikin and Bass 2000, 2002; Li et al. 2011; Du et al. 2015). Levien et al. (1979) measured the unit-cell parameters of pyrope in a diamond anvil cell at pressures up to $5 \mathrm{GPa}$ using a single crystal X-ray diffraction method, and obtained the bulk modulus $K_{0}=175$ (1) GPa and $K_{0}^{\prime}=4.5$ (5). Leitner et al. (1980) determined the elastic moduli of a synthetic single crystal of pyrope using Brillouin spectroscopy, and reported $K_{0}=175(1) \mathrm{GPa}$. Subsequently, Leger et al. (1990) used this $K_{0}$ value and using powder X-ray diffraction to report $K_{0}^{\prime}=3.4$ for pure synthetic pryope. Zhang et al. (1998) also investigated the equation of state and crystal structure of pyrope under hydrostatic conditions up to $33 \mathrm{GPa}$ using single crystal X-ray diffraction, and obtained $K_{0}=171(2) \mathrm{GPa}$ and $K_{0}^{\prime}=4.4$ (2). In addition, Conrad et al. (1999) conducted high-pressure Brillouin scattering experiments on near end-member single crystal pyrope at pressures up to $10 \mathrm{GPa}$ in a diamond-anvil cell with a methanol-ethanol-water pressure medium, and calculated $K_{0}$ and $K_{0}^{\prime}$ as $171.3 \mathrm{GPa}$ and 3.22, respectively. Sinogeikin and Bass (2000) also measured the single-crystal elastic properties of synthetic pyrope up to $20 \mathrm{GPa}$ using a Brillouin scattering method, and reported that the $K_{0}$ and $K_{0}^{\prime}$ were 169.4(20) GPa and 4.1 (3), respectively. In contrast, studies using synthetic polycrystalline specimens and ultrasonic interferometry in a 1000 ton split-cylinder multi-anvil apparatus (Chen et al. 1999) yielded $K_{0}=$ 171 (2) and $K_{0}^{\prime}=5.3$ (4), the largest value of $K_{0}^{\prime}$ in the previous studies for anhydrous pyrope. 
Recently, Du et al. (2015) also measured the unit-cell parameters of synthetic pyrope up to $10 \mathrm{GPa}$ using synchrotron X-ray powder diffraction, and yielded $K_{0}=169.2$ (2) by fixing $K_{0}^{\prime}$ at 4.4 which taken from Zhang et al. (1998). From the results of these previous studies, the anhydrous pyrope bulk modulus and its pressure derivative are within the ranges of $K_{0}=170-175 \mathrm{GPa}$ and $K_{0}^{\prime}=$ 3.2-5.3. However, we obtained the bulk modulus and its pressure derivative as $K_{0}=161 \mathrm{GPa}$ and $K_{0}^{\prime}=5.0$ for the hydrous pyrope (about $900 \mathrm{ppmw}$ ) in this study. The $K_{0}$ value of our hydrous pyrope was around 5-7 \% smaller than the anhydrous pyrope from previous studies, but its $K_{0}^{\prime}$ value was slightly larger. This phenomenon is similar to the effects of water on the elastic properties of olivine, reducing $K_{0}$ and increasing $K_{0}^{\prime}$ (Smyth et al. 2005; Jacobsen 2006) although unchanged $K_{0}^{\prime}$ for hydrous olivine was also proposed (Chen et al. 2011).

Wang et al. (1998) measured the $P-V-T$ relations of pyrope garnet at pressure and temperature conditions up to $11 \mathrm{GPa}$ and $1163 \mathrm{~K}$ with energy-dispersive synchrotron X-ray diffraction in a cubic-anvil, DIA-6 type apparatus. By fixing $K_{0}^{\prime}=5$, they obtained $K_{0}=170(2) \mathrm{GPa},\left(\partial K_{0} / \partial T\right)_{P}$ $=-0.020(3) \mathrm{GPaK}^{-1}$, and $\alpha_{0}=2.58(28) \times 10^{-5} \mathrm{~K}^{-1}$. Sinogeikin and Bass (2002) presented the single-crystal elasticity of pure synthetic pyrope at temperatures up to $800^{\circ} \mathrm{C}$ using Brillouin light scattering spectroscopy in a ceramic high-temperature cell, indicating $K_{0}=169(2) \mathrm{GPa}$ and $\left(\partial K_{0} / \partial T\right)_{P}=-0.019(3) \mathrm{GPaK}^{-1}$. Gwanmesia et al. (2006) determined the acoustic wave velocities of synthetic polycrystalline pyrope up to $9 \mathrm{GPa}$ and $1000^{\circ} \mathrm{C}$ by ultrasonic interferometry combined with energy-dispersive synchrotron X-ray diffraction in a cubic-anvil DIA-type apparatus, and obtained $K_{0}=172(2) \mathrm{GPa}$ and $\left(\partial K_{0} \partial T\right)_{P}=-0.026(4) \mathrm{GPaK}^{-1}$ by fixing $K_{0}^{\prime}=3.9$. Recently, Zou et al. (2012) measured the thermoelastic properties of synthetic pyrope garnet at higher pressure and temperature conditions (up to $19 \mathrm{GPa}$ and $1700 \mathrm{~K}$ ) using in situ energy-dispersive synchrotron X-ray diffraction combined with a Kawai-type multi-anvil apparatus, and concluded that $K_{0}=167(3) \mathrm{GPa},\left(\partial K_{0} / \partial T\right)_{P}=-0.021(9) \mathrm{GPaK}^{-1}$, and $\alpha_{0}=2.89(33) \times 10^{-5} \mathrm{~K}^{-1}$ for fixed $K_{0}^{\prime}=4.6$. Du et al. (2015) also investigated the thermo-compression of a series of synthetic garnets with the pyrope, grossular, and intermediate compositions up to about $900 \mathrm{~K}$ and to $10 \mathrm{GPa}$ using synchrotron X-ray powder diffraction with a diamond anvil cell, and obtained $\alpha_{0}=2.74(5) \times 10^{-5}$ $\mathrm{K}^{-1}$ for end-member pyrope. The results of previous studies indicate that the temperature derivative of anhydrous pyrope bulk modulus $\left(\left(\partial K_{0} / \partial T\right)_{P}\right)$ ranges from $-0.019 \mathrm{GPaK}^{-1}$ to -0.026 $\mathrm{GPaK}^{-1}$, and the coefficients of thermal expansion $\left(\alpha_{0}\right)$ range from $2.58 \times 10^{-5} \mathrm{~K}^{-1}$ to $2.89 \times 10^{-5} \mathrm{~K}^{-1}$. 
However, we obtained $\left(\partial K_{0} / \partial T\right)_{P}=-0.018(4) \mathrm{GPaK}^{-1}$ and $\alpha_{0}=3.2(1) \times 10^{-5} \mathrm{~K}^{-1}$ for hydrous pyrope (about $900 \mathrm{ppmw}$ ) in this study. The $(\partial K / \partial T)_{P}$ value of the hydrous pyrope in this study is in agreement with anhydrous pyrope, whereas the $\alpha_{0}$ value of the hydrous pyrope is slightly larger than anhydrous pyrope. Lu et al. (2013) measured the single-crystal elasticity of natural Fe-bearing pyrope using in situ Brillouin spectroscopy and X-ray diffraction at high-pressure and temperature conditions up to $20 \mathrm{GPa}$ and $750 \mathrm{~K}$ in an externally-heated diamond anvil cell, and found $\left(\partial K_{0} / \partial T\right)_{P}=-0.023(2) \mathrm{GPaK}^{-1}$ for Fe-bearing pyrope, which is very consistent with the results from Wang et al. (1998) $\left(\left(\partial K_{0} / \partial T\right)_{P}=-0.020(3) \mathrm{GPaK}^{-1}\right)$ and Zou et al. (2012) $\left(\left(\partial K_{0} / \partial T\right)_{P}\right.$ $\left.=-0.021(9) \mathrm{GPaK}^{-1}\right)$ for pure pyrope using a synchrotron X-ray diffraction method within their uncertainties. Therefore, based on the existing data, we believe that the temperature derivative of the pyrope bulk modulus may not be significantly affected by its iron and hydrogen content; however, hydrogen can slightly raise the thermal expansion coefficient of pyrope.

\section{Geophysical Implications}

Earth's mantle mostly consists of nominally anhydrous minerals, such as olivine, pyroxenes, garnet, and their high-pressure equivalents (Williams and Hemley 2001). Although these minerals do not contain $\mathrm{OH}$ groups in their formulas, they can dissolve traces of $\mathrm{OH}$ as point defects (Hirschmann 2006). Investigations of natural samples suggest that these minerals may represent a major reservoir of water in the Earth (e.g. Rossman and Smyth 1990; Skogby et al. 1990; Smyth et al. 1991; Bell and Rossman 1992a, 1992b; Rossman 1996; Bell et al. 2003). Pyrope occurs commonly in nature both as a metamorphic mineral and as a high-pressure phase, which is stable under upper mantle conditions (Leitner et al. 1980), and it is probably also important in the mantle-transition zone (420-670 km) depth phases (Duffy and Anderson 1989). Furthermore, previous studies also predicted that pyrope could incorporate significant amounts of water as hydroxyl (e.g. Bell and Rossman 1992b; Bell et al. 1995; Beran and Libowitzky 2006). Therefore, using the newly-determined thermoelastic properties of hydrous pyrope in our present study, we calculated the density profiles of the major upper-mantle minerals.

We used high-temperature BM-EoS to calculate the densities of the following constituent minerals at conditions corresponding to the upper mantle: olivine $\left(\left(\mathrm{Mg}_{0.9} \mathrm{Fe}_{0.1}\right)_{2} \mathrm{SiO}_{4}\right)(\mathrm{Liu}$ and $\mathrm{Li}$ 
2006), orthopyroxene $\left(\mathrm{MgSiO}_{3}\right)$ (Shinmei et al. 1999), clinopyroxene (omphacite- $\mathrm{Di}_{63} \mathrm{Jd}_{37}$; $\left.\mathrm{Di}=\mathrm{Ca}(\mathrm{Mg}, \mathrm{Fe}) \mathrm{Si}_{2} \mathrm{O}_{6}, \mathrm{Jd}=\mathrm{NaAlSi}_{2} \mathrm{O}_{6}\right)$ (Nishihara et al. 2003), anhydrous pyrope $\left(\mathrm{Mg}_{3} \mathrm{Al}_{2} \mathrm{Si}_{3} \mathrm{O}_{12}\right)$ (Zou et al. 2012), and hydrous pyrope $\left(\mathrm{Mg}_{3} \mathrm{Al}_{2} \mathrm{Si}_{3} \mathrm{O}_{12}\right)$ (this study). As shown in previous studies, orthopyroxene with the space group Pbca transforms to high-pressure $C 2 / c$ clinoenstatite at the relevant pressure and temperature conditions of the upper mantle (e.g. Shinmei et al. 1999; Bromiley G and Bromiley F 2006; Yu and Wentzcovitch 2009; Finkelstein et al. 2015). Therefore we used the thermoelastic parameters determined for $C 2 / c$ clinoenstatite by Shinmei et al. (1999) in our calculations. In addition, the effect of iron incorporation on the elastic/thermoelastic properties of pyrope was studied experimentally (e.g. Lu et al. 2013; Huang and Chen 2014), and indicated that incorporation of a small amount of iron (about $25 \%$ ) in pyrope increases the pressure derivative of the bulk modulus by $7 \%$, but has a negligible effect on other thermoelastic parameters (Lu et al. 2013). The upper-mantle garnet is mainly composed of pyrope with 6 23\% iron substituting for magnesium (Richwood et al. 1968; Lee 2003), which has a smaller iron component than the iron-bearing pyrope sample used in the study by Lu et al. (2013). Thus in our calculations, we assumed that the incorporation of a small amount of iron $(<25 \%)$ has little effect on the thermoelastic properties of pyrope.

Figure 8 shows the density-profiles of the constituent minerals for the Earth's upper mantle region between a 200 and $400 \mathrm{~km}$ depth along a normal continental geotherm (Katsura et al. 2010). The PREM density-profile (Dziewonski and Anderson 1981) is also shown in Fig. 9 for comparison. Compared with the modeled densities of anhydrous pyrope (Zou et al. 2012) at the P-T conditions of the upper mantle, our results show that the hydrogen effect on thermoelasticity of pyrope leads to a $\sim 1 \%$ decrease in the density. In addition, the density profiles of olivine, orthopyroxene, and clinopyroxene are also modeled using existing results on their thermoelasticity parameters (Liu and Li 2006; Shinmei et al. 1999; Nishihara et al. 2003). The density profile of hydrous pyrope is $\sim 6 \%$ higher than the PREM density profile, but closer to the PREM than the anhydrous pyrope density profile. Furthermore, the density profile of orthopyroxene is $\sim 1.5 \%$ higher than the PREM density profile, whereas the density profiles of olivine and clinopyroxene are very close to the PREM density profile.

To better understand the density profiles and mineralogical models of the upper mantle, we also modeled the density profiles of two representative upper-mantle mineral assemblages, piclogite 
and pyrolite, using the updated thermoelastic properties of hydrous pyrope for the Earth's upper mantle region between 200 and $400 \mathrm{~km}$ depth (Fig. 9). The pyrolite and piclogite models represent two global mineral compositions of the upper mantle that are commonly used for comparison between mineral physics results and global density profiles (Lu et al. 2013). The mineral assemblage in pyrolite model includes $\sim 63 \%$ olivine, $\sim 15 \%$ garnet, $\sim 16 \%$ clinopyroxene, and $\sim 6 \%$ orthopyroxene, whereas the piclogite model includes $\sim 43 \%$ olivine, $\sim 15 \%$ garnet, $\sim 36 \%$ clinopyroxene, and $\sim 6 \%$ orthopyroxene (Ita and Stixrude 1992). Here we made two assumptions: first, the chemical compositions of the constituent minerals do not change in this P-T range, which results in constant zero-pressure densities of the constituent minerals; and second, the volume proportions of the constituent minerals of piclogite and pyrolite models are constant. The results are shown in Fig. 9 and Fig. 10, and the PREM density profile is also shown in these figures for comparison. Fig. 9 shows that the piclogite and pyrolite models with hydrous pyrope match very well with each other, however, the modeled density profiles of both the piclogite and pyrolite models with hydrous pyrope are $\sim 1.5 \%$ higher than the PREM density profile (Fig. 9). Fig. 10 shows the density profiles of pyrolite with hydrous pyrope and pyrolite with anhydrous pyrope at Earth's upper mantle region between a 200 and $400 \mathrm{~km}$ depth. The density profiles of both are higher than the PREM density profile, but the density profile of pyrolite with hydrous pyrope is slightly closer to the PREM density profile than pyrolite with anhydrous pyrope, which shows that hydrogen in pyrope can decrease the density of the pyrolite model towards the PREM. Furthermore, considering that the volume proportion of pyrope in the piclogite and pyrolite models is relatively small compared with olivine and pyroxene, incorporating water into the olivine and pyroxene of the upper mantle may make the density profiles of the pyrolite and piclogite models match the PREM density profile well. This once again proves that the nominally anhydrous mineral phases in the Earth's upper mantle (olivine, pyroxene, and garnet) can contain a significant amount of hydrogen. However, this still needs to be confirmed by measuring the thermoelasticity of all major hydrous upper mantle minerals at relevant P-T conditions in future experiments. 


\section{Conclusions}

Incorporating $900 \mathrm{ppmw}$ of water in pyrope crystal yields a reduction in its bulk modulus of $7 \%$, a slight increase in its bulk modulus pressure derivative and thermal expansion coefficient, but little change in its bulk modulus temperature derivative. The presence of water in pyrope helps to reduce the densities of the pyrolite and piclogite models to better match the density profile of the PREM. Incorporating water in olivine and pyroxene is favorable for reconciling the discrepancy in the density profiles between the mineral physics models and the seismological model (PREM).

\section{Acknowledgments}

D. W. Fan acknowledges financial support from the National Natural Science Foundation of China (41374107), and the Joint Research Fund in Huge Scientific Equipment (U1632112) under cooperative agreement between the National Natural Science Foundation of China and Chinese Academy of Sciences. J. H. Chen acknowledges financial support from the National Science Foundation of US (EAR-0711321). J. G. Xu acknowledges financial support from the Strategic Priority Research Program (B) of the Chinese Academy of Sciences (XDB18010401). The high temperature and high pressure powder X-ray diffraction experiments were performed at the High Pressure Experiment Station (4W2), Beijing Synchrotron Radiation Facility (BSRF). The room temperature and high pressure single crystal X-ray diffraction experiments were performed at the BL15U1 of the Shanghai Synchrotron Radiation Facility (SSRF).

\section{References}

Aines, R.D., Rossman, G.R., 1984. Water in minerals? A peak in the infrared. J. Geophys. Res. 89, 4059-4071.

Akaogi, M., Akimoto, S, 1977. Pyroxene-garnet solid-solution equilibria in the systems $\mathrm{Mg}_{4} \mathrm{Si}_{4} \mathrm{O}_{12}-\mathrm{Mg}_{3} \mathrm{Al}_{2} \mathrm{Si}_{3} \mathrm{O}_{12}$ and $\mathrm{Fe}_{4} \mathrm{Si}_{4} \mathrm{O}_{12}-\mathrm{Fe}_{3} \mathrm{Al}_{2} \mathrm{Si}_{3} \mathrm{O}_{12}$ at high pressures and temperatures. Phys. Earth Planet. Inter. 15, 90-106.

Anderson, D.L., Bass, J., 1984. Mineralogy and composition of the upper mantle. Geophys. Res. Lett. 11, 637-640. 
Anderson, O.L., 1995. Equation of State of Solids for Geophysics and Ceramic Science. Oxford University Press, New York, pp.243-274.

Angel, R. J., 2000. Equation of state. Rev. Mineral. Geochem. 41, 35-60.

Angel, R.J., Bujak, M., Zhao, J., Gatta, G.D., Jacobsen, S.D., 2007. Effective hydrostatic limits of pressure media for high-pressure crystallographic studies. J. Appl. Crystallogr. 40, 26-32.

Bass, J.D., Liebermann, R.C., Weidner, D.J., Finch, S.J., 1981. Elastic properties from acoustic and volume compression experiments. Phys. Earth Planet. Inter. 25, 140-158.

Bell, D. R., Ihinger, P. D., Rossman, G. R., 1995. Quantitative analysis of trace OH in garnet and pyroxenes. Am. Mineral. 80, 465-474.

Bell, D.R., Rossman, G.R., 1992a. Water in Earth's mantle: The role of nominally anhydrous minerals. Science 255, 1391-1397.

Bell, D.R., Rossman, G.R., 1992b. The distribution of hydroxyl in garnets from the subcontinental mantle of southern Africa. Contrib. Min. Petrol. 111, 161-178.

Bell, D.R., Rossman, G.R., Maldener, J., Endisch, D., Rauch, F., 2003. Hydroxide in olivine: a quantitative determination of the absolute amount and calibration of the IR spectrum. J. Geophys. Res. 108, 2105.

Beran, A., Libowitzky, E., 2006. Water in natural mantle minerals II: olivine, garnet and accessory Minerals. Rev. Mineral. Geochem. 62, 169-191.

Bonczar, L.J., Graham, E.K., 1977. The pressure and temperature dependence of the elastic constants of pyrope garnet. J. Geophys. Res. 82, 2529-2534.

Bromiley, G.D., Bromiley, F.A., 2006. High-pressure phase transitions and hydrogen incorporation into MgSiO3 enstatite. Am. Mineral., 91, 1094-1101.

Chen, J., Inoue, T., Weidner, D. J., Wu, Y. Vaughan, M. T., 1998. Strength and Water Weakening of Mantle Minerals, Olivine, Wadsleyite and Ringwoodite, Geophys. Res. Lett. 25, 575-578 \& 1103-1104

Chen, J., Liu H., Girard J., 2011. Comparative in situ X-ray diffraction study of San Carlos olivine: Influence of water on the $410 \mathrm{~km}$ seismic velocity jump in Earth's mantle. Am. Mineral. 96 $(5-6), 697-702$

Chen, G., Cooke, J.A.J., Gwanmesia, G.D., Liebermann, R.C., 1999. Elastic wave velocities of $\mathrm{Mg}_{3} \mathrm{Al}_{2} \mathrm{Si}_{3} \mathrm{O}_{12}$-pyrope garnet to $10 \mathrm{GPa}$. Am. Mineral. 84, 384-388. 
Conrad, P.G., Zha, C.S., Mao, H.K., Hemley, R.J., 1999. The high-pressure, single-crystal elasticity of pyrope, grossular, and andradite. Am. Mineral. 84, 374-383.

Deer, W.A., Howie, R.A., Zussman, J., 1992. An introduction to the rock-forming minerals. John Wiley, New York.

Dera, P., Zhuravlev, K., Prakapenka, V., Rivers, M.L., Finkelstein, G.J., Grubor-Urosevic, O., Tschauner, O., Clark, S.M., Downs, R.T., 2013. High pressure single-crystal micro X-ray diffraction analysis with GSE_ADA/RSV software. High Press. Res. 33, 466-484.

Du, W., Clark, S.M., Walker, D., 2015. Thermo-compression of pyrope-grossular garnet solid solutions: Non-linear compositional dependence. Am. Mineral. 100, 215-222.

Duffy, T.S., Anderson, D.L., 1989. Seismic velocity in mantle minerals and mineralogy of the upper mantle. J. Geophys. Res. 94, 1895-1912.

Dziewonski, A.M., Anderson, D.L., 1981. Preliminary reference Earth model. Phys. Earth Planet. Inter. 25, 297-356.

Fan, D.W., Ma, M.N., Wei, S.Y., Chen, Z.Q., Xie, H.S., 2013. High Pressure Elastic Behavior of Synthetic $\mathrm{Mg}_{3} \mathrm{Y}_{2}\left(\mathrm{SiO}_{4}\right)_{3}$ Garnet up to 9GPa. Adv. Mater. Sci. Eng. 2013, 502702.

Fan, D.W., Zhou, W.G., Wei, S.Y., Liu, Y.G., Ma, M.N., Xie, H.S., 2010. A simple external resistance heating diamond anvil cell and its application for synchrotron radiation $\mathrm{x}$-ray diffraction. Rev. Sci. Instrum. 81, 053903.

Fei, Y.W., Ricolleau, A., Frank, M., Mibe, K., Shen, G.Y., Prakapenka, V., 2007. Toward an internally consistent pressure scale. PNAS 104, 9182-9186.

Finkelstein, G.J., Dera, P.K., Duffy, T.S., 2015. Phase transitions in orthopyroxene (En90) to 49 GPa from single-crystal X-ray diffraction. Phys. Earth Planet. Inter. 244, 78-86.

Flanagan, M.P., Shearer, P.M., 1999. A map of topography on the 410-km discontinuity from PP precursors. Geophys. Res. Lett. 26, 549-552.

Gasparik, T., 2000. Evidence for immiscibility in majorite garnet from experiments at 13-15 GPa. Geochim. Cosmochim. Ac. 64, 1641-1650.

Guyot, F., Wang, Y., Gillet, P., Ricard, Y., 1996. Quasiharmonic computations of thermodynamic parameters of olivines at high pressure and high temperature: a comparison with experiment data. Phys. Earth Planet. Inter. 98, 17-29.

Gwanmesia, G.D., Zhang, J.Z., Darling, K., Kung, J., Li, B.S., Wang, L.P., Neuville, D., 
Liebermann, R.C., 2006. Elasticity of polycrystalline pyrope $\left(\mathrm{Mg}_{3} \mathrm{Al}_{2} \mathrm{Si}_{3} \mathrm{O}_{12}\right)$ to $9 \mathrm{GPa}$ and $1000{ }^{\circ} \mathrm{C}$. Phys. Earth Planet. Inter. 155, 179-190.

Hammersley, A.P., Svensson, S.O., Hanfland, M., Fitch, A.N., Hausermann, D., 1996. Two-dimensional detector software: from real detector to idealized image or two-theta scan. High Pressure Res. 14, 235-248.

Hazen, R.M., Finger, L.W., 1978. Crystal structures and compressibilities of pyrope and grossular to 60 kbar. Am. Mineral. 63, 297-303.

Hickmott, D.D., 1989. Rare Earth Element Zoning in Pyrope-Rich Garnets from Mantle Xenoliths, Carnegie Institution, Washington Year Book 1988-1989, No. 2150, pp. 6-10.

Hickmott, D.D., Shimizu, N., Spear, F.S., Selverstone, J., 1987. Trace-element zoning in a metamorphic garnet. Geology 15, 573-576.

Hirschmann, M.M., 2006. Water, Melting, and the Deep Earth $\mathrm{H}_{2} \mathrm{O}$ Cycle. Ann. Rev. Earth Planet. Sci. 34, 629-653.

Huang, S., Chen, J.H., 2014. Equation of state of pyrope-almandine solid solution measured using a diamond anvil cell and in situ synchrotron X-ray diffraction. Phys. Earth Planet. Inter. 228, $88-91$.

Huang, X., Xu, Y., Karato, S., 2005. Water content in the Transition Zone from electrical conductivity of wadsleyite and ringwoodite. Nature 434, 746-749.

Irifune, T., Ringwood, A.E., 1987. Phase transformations in primitive MORB and pyrolite compositions to $25 \mathrm{GPa}$ and some geophysical implications, in High Pressure Research in Mineral Physics, Geophysical Monograph Series, vol. 39, edited by M. Manghnani and Y. Syono, pp. 231-242, AGU, Washington, D. C.

Irifune, T., Ringwood, A.E., 1993. Phase transformations in subducted oceanic crust and buoyancy relationships at depths of 600-800 km in the mantle. Earth Planet. Sci. Lett. 117, 101-110.

Ita, J., Stixrude, L., 1992. Petrology, elasticity, and composition of the mantle transition zone. J. Geophys. Res. 97, 6849-6866.

Jackson, I., Rigden, S.M., 1996. Analysis of P-V-T data: constraints on the thermoelastic properties of high-pressure minerals. Phys. Earth Planet. Inter. 96, 85-112.

Jacobsen, S.D., 2006 Effect of water on the equation of state of nominally anhydrous minerals. In H.J. Keppler and J.R. Smyth, Eds., Water in Nominally Anhydrous Minerals, 62, p. 321-342. 
Rev. Mineral. Geochem., Mineralogical Society of America, Chantilly, Virginia.

Jung, H., Karato, S., 2001. Water induced fabric transitions in olivine. Science 293, 1460-1463.

Karato, S., 1990. The role of hydrogen in the electrical conductivity of the upper mantle. Nature $347,272-273$.

Karato, S., 2006. Influence of hydrogen-related defects on the electrical conductivity and plastic deformation of mantle minerals: A Critical Review. In S.D. Jacobsen and S. van der Lee, Eds., Earth's Deep Water Cycle, 168, p. 113-129. American Geophysical Union, Geophysical Monograph Series, Washington, D.C.

Karato, S., Wang, Z., Liu, B., Fujino, K., 1995. Plastic deformation of garnets: systematics and implications for the rheology of the mantle transition zone. Earth Planet. Sci. Lett. 130, $13-30$.

Katsura, T., Yoneda, A., Yamazaki, D., Yoshino, T., Ito, E., 2010. Adiabatic temperature profile in the mantle. Phys. Earth Planet. Inter. 183, 212-218.

Kavner, A., 2003. Elasticity and strength of hydrous ringwoodite at high pressure. Earth Planet. Sci. Lett. 214, 645-654.

Kohlstedt, D.L., Keppler, H., Rubie, D.C., 1996. Solubility of water in the $\alpha$-phase, $\beta$-phase and $\gamma$-phase of $(\mathrm{Mg}, \mathrm{Fe})_{2} \mathrm{SiO}_{4}$. Contrib. Min. Petrol. 123, 345-357.

Kubo, T., Ohtani, E., Kato, T., Shinmei, T., Fujino, K., 1998. Effect of water on the $\alpha-\beta$ transformation kinetics in San Carlos olivine. Science 281, 85-87.

Larson A.C., Von Dreele R.B., 2000. GSAS general structure analysis system operation manual. Los Alamos National Laboratory LAUR 86-748, 1-179.

Le Bail A., Duroy H., Fourquet J.L., 1988. Ab initio structure determination of $\mathrm{LiSbWO}_{6}$ by X-ray powder diffraction. Mater. Res. Bull. 23, 447-452.

Lee, C.T.A., 2003. Compositional variation of density and seismic velocities in natural peridotites at STP conditions: implications for seismic imaging of compositional heterogeneities in the upper mantle. J. Geophys. Res. 108, 2441-2461.

Leger, J.M., Redon, A.M., Chateau, C., 1990. Compressions of Synthetic Pyrope, Spessartine and Uvarovite Garnets up to 25 GPa. Phys. Chem. Miner. 17, 161-167.

Leitner, B.J., Weidner, D.J., Liebermann, R.C., 1980. Elasticity of single crystal pyrope and implications for garnet solid solution series. Phys. Earth Planet. Inter. 22, 111-121. 
Levien, L., Prewitt, C.T., Weidner, D.J., 1979. Compression of pyrope. Am. Mineral. 64, 805-808.

Li, L., Weidner, D.J., Brodholt, J., Alfe, D., Price, G.D., 2011. Ab Initio Molecular Dynamic Simulation on the Elasticity of $\mathrm{Mg}_{3} \mathrm{Al}_{2} \mathrm{Si}_{3} \mathrm{O}_{12}$ Pyrope. J. Earth Sci. 22, 169-175.

Liu, W., Li, B.S., 2006. Thermal equation of state $\left(\mathrm{Mg}_{0.9} \mathrm{Fe}_{0.1}\right)_{2} \mathrm{SiO}_{4}$ olivine. Phys. Earth Planet. Inter. 157, 188-195.

Lu, C., Mao, Z., Lin, J.F., Zhuravlev, K.K., Tkachev, S.N., Prakapenka, V.B., 2013. Elasticity of single-crystal iron-bearing pyrope up to $20 \mathrm{GPa}$ and $750 \mathrm{~K}$. Earth Planet. Sci. Lett. 361, 134-142.

Lu, R., Keppler, H., 1997. Water solubility in pyrope to 100 kbar. Contrib. Min. Petrol. 129, 35-42.

Mackwell, S.J., Kohlstedt, D.L., 1990. Diffusion of hydrogen in olivine: implications for water in the mantle. J. Geophys. Res. 95, 5079-5088.

Mao, H.K., Bell, P.M., Shaner, J.W., Steinberg, D.J., 1978. Specific volume measurements of Cu, Mo, Pd, and Ag and calibration of the ruby R1 fluorescence pressure gauge from 0.06 to 1 Mbar. J. Appl. Phys. 49, 3276-3283.

Mei, S., Kohlstedt, D.L., 2000. Influence of water on plastic deformation of olivine aggregates 1. Diffusion creep regime. J. Geophys. Res. 105, 21457-21469.

Mookherjee, M., Karato, S., 2010. Solubility of water in pyrope-rich garnet at high pressures and temperature. Geophys. Res. Lett. 37, L03310.

Nishihara, Y., Takahashi, E., Matsukage, K.N., Iguchi, T., Nakayama, K., Funakoshi, K., 2004. Thermal equation of state $\left(\mathrm{Mg}_{0.91} \mathrm{Fe}_{0.09}\right)_{2} \mathrm{SiO}_{4}$ ringwoodite. Phys. Earth Planet. Inter. 143-144, $33-46$.

Nishihara, Y., Takahashi, E., Matsukage, K.N., Kikegawa, T., 2003. Thermal equation of state of omphacite. Am. Mineral. 88, 80-86.

Ohtani, E., 2005. Water in the Mantle. Elements 1, 25-30.

O’Neill, B., Bass, J.D., Rossman, G.R., 1993. Elastic properties of hydrogrossular garnet and implications for water in the upper mantle. J. Geophys. Res. 98, 20031-20037.

Passaglia, E., Rinaldi, R., 1984. Katoite, a new member of the $\mathrm{Ca}_{3} \mathrm{Al}_{2}\left(\mathrm{SiO}_{4}\right)_{3}-\mathrm{Ca}_{3} \mathrm{Al}_{2}(\mathrm{OH})_{12}$ series and a new no-menclature for the hydrogrossular group of minerals. Bull. Minéral. 107, 605-618.

Pavese, A., Diella, V., Pischedda, V., Merli, M., Bocchio, R., Mezouar, M., 2001. 
Pressure-volume-temperature equation of state of andradite and grossular, by high-pressure and -temperature powder diffraction. Phys. Chem. Miner. 28, 242-248.

Piermarini, G.J., Block, S., Barnett, J.D. (1973) Hydrostatic limits in liquids and solids to $100 \mathrm{kbar}$. Journal of Applied Physics, 44, 5377-5382.

Richwood, P.C., Mathias, M., Siebert, J.C., 1968. A study of garnets from eclogite and peridotite xenoliths found in kinberlite. Contrib. Min. Petrol. 19, 271-301.

Ringwood, A.E., 1991. Phase transformations and their bearing on the constitution and dynamics of the mantle. Geochim. Cosmochim. Ac. 55, 2083-2110.

Rossman, G.R., 1996. Studies of OH in nominally anhydrous minerals. Phys. Chem. Miner. 23, 299-304.

Rossman, G.R., Aines, R.D., 1991. The hydrous components in garnets: grossular-hydrogrossular. Am. Mineral. 76, 1153-1164.

Rossman, G.R., Smyth, J.R., 1990. Hydroxyl contents of accessory minerals in mantle eclogites and related rocks. Am. Mineral. 75, 775-780.

Sato, Y., Akaogi, M., Akimoto, S., 1978. Hydrostatic compression of the synthetic garnets pyrope and almandine. J. Geophys. Res. 83, 335-338.

Shinmei, T., Tomioka, N., Fujino, K., Kuroda, K., Irifune, T., 1999. In situ X-ray diffraction study of enstatite up to $12 \mathrm{GPa}$ and $1473 \mathrm{~K}$ and equations of state. Am. Mineral. 84, 1588-1594.

Sinogeikin, S.V., Bass, J.D., 2000. Single-crystal elasticity of pyrope and MgO to $20 \mathrm{GPa}$ by Brillouin scattering in the diamond cell. Phys. Earth Planet. Inter. 120, 43-62.

Sinogeikin, S.V., Bass, J.D., 2002. Elasticity of pyrope and majorite-pyrope solid solutions to high temperatures. Earth Planet. Sci. Lett. 203, 549-555.

Skogby, H., 2006. Water in natural mantle minerals I: Pyroxenes. Rev. Mineral. Geochem. 62, 155-167.

Skogby, H., Bell, D.R., Rossman, G.R., 1990. Hydroxide in pyroxene: variations in the natural environment. Am. Mineral. 75:764-774.

Smyth, J.R., Bell, D.R., Rossman, G.R., 1991. Incorporation of hydroxyl in upper-mantle clinopyroxenes. Nature 351, 732-735.

Smyth, J.R., Frost, D.J., Nestola, F., 2005. Hydration of olivine and the Earth's deep water cycle. Geochim. Cosmochim. Ac. 69, A746. 
Smyth, J.R., Holl, C.M., Frost, D.J., Jacobsen, S.D., Langenhorst, F., McCammon, C.A., 2003. Structural systematics of hydrous ringwoodite and water in Earth's interior. Am. Mineral. 88, $1402-1407$.

Smyth, J.R., Jacobsen, S.D., Hazen, R.M., 2000. Comparative crystal chemistry of orthosilicate minerals. Rev. Mineral. Geochem. 41, 187-209.

Smyth, J.R., Mierdel, K., Keppler, H., Langenhorst, F., Dubrovinsky, L., Nestola, F., 2007. Crystal chemistry of hydration in aluminous orthopyroxene. Am. Mineral. 92, 973-976.

Tenner, T.J., Hirschmann, M.M., Withers, A.C., Ardia, P., 2012. $\mathrm{H}_{2} \mathrm{O}$ storage capacity of olivine and low-Ca pyroxene from 10 to $13 \mathrm{GPa}$ : consequences for dehydration melting above the transition zone. Contrib. Min. Petrol. 163, 297-316.

Tenner, T.J., Hirschmann, M.M., Withers, A.C., Hervig, R.L., 2009. Hydrogen partitioning between nominally anhydrous upper mantle minerals and melt between 3 and $5 \mathrm{GPa}$ and applications to hydrous peridotite partial melting. Chem. Geol. 262, 42-56.

Toby, B.H., 2001. EXPGUI, a graphical user interface for GSAS. J. Appl. Crystallogr. 34, 210-213.

Wang, Y., Weinder, D.J., Guyot, F., 1996. Thermal equation of state of $\mathrm{CaSiO}_{3}$ perovskite. J. Geophys. Res. 101, 661-672.

Wang, Y.B., Weidner, D.J., Zhang, J.Z., Gwanrnesia, G.D., Liebermann, R.C., 1998. Thermal equation of state of garnets along the pyrope-majorite join. Phys. Earth Planet. Inter. 105, $59-71$.

Wang, Z.C., Ji, S.C., 2001. Elasticity of six polycrystalline silicate garnets at pressure up to 3.0 GPa. Am. Mineral. 86, 1209-1218.

Weidner, D.J., Wang, Y., 2000. Phase transformations: Implications for mantle structure, in Earth's Deep Interior: Mineral Physics and Tomography From the Atomic to the Global Scale, Geophysical Monograph Series, vol. 117, edited by S. I. Karato et al., pp. 215-235, AGU, Washington, D. C.

Williams, Q., Hemley, R.J., 2001. Hydrogen in the deep Earth. Ann. Rev. Earth Planet. Sci. 29, $365-418$.

Withers, A.C., Wood, B.J., Carroll, M.R., 1998. The OH content of pyrope at high pressure. Chem. Geol. 147, 161-171. 
Xie, H.S., Zhang, Y., Xu, H.G., Hou, W., Guo, J., Zhao, H., 1993. A new method of measurement for elastic wave velocities in minerals and rocks at high temperature and high pressure and its significance. Sci. China Chem. 36, 1276-1280.

Xie, H.S., Zhou, W.G., Liu, Y.G., Guo, J., Hou, W., Zhao, Z.D., 2002. Comparative experimental study on several methods for measuring elastic wave velocities in rocks at high pressure. Sci. China Earth Sci. 45, 990-998.

Yu, Y.G., Wentzcovitch, R.M., 2009. Low-pressure clino- to high-pressure clinoenstatite phase transition: A phonon-related mechanism. Am. Mineral. 94, 461-466.

Zhang, L., Ahsbahs, H., Kutoglu, A., 1998. Hydrostatic compression and crystal structure of pyrope to 33 GPa. Phys. Chem. Miner. 25, 301-307.

Zou, Y.T., Gréaux, S., Irifune, T., Whitaker, M.L., Shinmei, T., Higo, Y., 2012. Thermal equation of state of $\mathrm{Mg}_{3} \mathrm{Al}_{2} \mathrm{Si}_{3} \mathrm{O}_{12}$ pyrope garnet up to $19 \mathrm{GPa}$ and $1700 \mathrm{~K}$. Phys. Chem. Miner. 39, 589-598. 
Fig. 1 FTIR spectra of synthetic pyrope garnet for the wave-number range of $3300-3750 \mathrm{~cm}^{-1}$

Fig. 2 Le Bail profile fitting of the hydrous pyrope diffraction profiles at $13.21 \mathrm{GPa}$ and $900 \mathrm{~K}$. Observed spectra (black line), fitted spectra (red solid line), difference plot (blue solid line) and Bragg peak positions (tick marks) are shown. (Color online)

Fig. 3 Volume compression of hydrous pyrope at high pressure and room temperature from single-crystal X-ray diffraction experiments compared with the powder X-ray diffraction experiments in this study. The third-order BM EoS fitted with $K_{0}$ and $K_{0}^{\prime}$ are $161 \mathrm{GPa}$ and 5.0 for hydrous pyrope. The error bars of the data points are smaller than the symbols.

Fig. 4 Volume Eulerian strain-normalized pressure $\left(F_{E}-f_{E}\right)$ plot of hydrous pyrope. The solid line represents the linear fit through the data.

Fig. 5 Unit-cell volume of hydrous pyrope as a function of pressure and temperature. The solid lines represent the isothermal compression curve from fitting the HTBM EoS at 300, 500, 700, $900 \mathrm{~K}$ with the following parameters: $K_{0}=162 \pm 1 \mathrm{GPa}, K_{0}^{\prime}=4.9 \pm 0.2,\left(\partial K_{0} / \partial T\right)_{P}=-0.018 \pm 0.004 \mathrm{GPaK}^{-1}$ and $\alpha_{0}=(3.19 \pm 0.10) \times 10^{-5} \mathrm{~K}^{-1}$. The error bars of the data points are smaller than the symbols.

Fig. 6 Thermal pressure of hydrous pyrope verses temperature. Solid circles are the hydrous pyrope data in this study. The solid line is the fitting results using a thermal pressure approach.

Fig. 7 Variations of thermal pressure with the unit-cell volume at various temperatures. The dashed lines correspond to the constant values of thermal pressure for a given temperature. The data indicates that $\left(\partial K_{T} / \partial T\right)_{V}$ is close to zero.

Fig. 8 Calculated density profiles of constituent minerals in the upper mantle between 200 and $400 \mathrm{~km}$. Anhydrous pyrope (black solid line), Hydrous pyrope (red solid line), Olivine (blue solid line), Opx (magenta solid line), Cpx (olive solid line). The PREM density profile is also shown (dashed line).

Fig. 9 Calculated density profiles of piclogite and pyrolite models. In these calculations, the zero-pressure densities and mineral proportions of the constituent minerals are assumed to be constant. The PREM density profile is also shown (dashed line).

Fig. 10 Calculated density profiles of pyrolite models with hydrous pyrope and with anhydrous pyrope. In these calculations, the zero-pressure densities and mineral proportions of the constituent minerals are assumed to be constant. The PREM density profile is also shown (dashed line). 
Table 1 Unit cell parameters of hydrous pyrope from single-crystal X-ray diffraction data at high

\begin{tabular}{cc}
\multicolumn{2}{c}{ pressure and room temperature } \\
\hline $\mathrm{P}(\mathrm{GPa})$ & $\mathrm{V}\left(\AA^{3}\right)$ \\
\hline 0.0001 & $1505.24(8)$ \\
$0.45(3)$ & $1500.52(7)$ \\
$1.32(11)$ & $1492.75(8)$ \\
$2.28(37)$ & $1484.54(8)$ \\
$3.44(28)$ & $1474.38(9)$ \\
$4.73(36)$ & $1463.56(8)$ \\
$5.62(47)$ & $1457.87(10)$ \\
$6.47(38)$ & $1451.35(8)$ \\
$7.59(43)$ & $1442.13(10)$ \\
$8.73(52)$ & $1433.85(9)$ \\
$9.81(48)$ & $1427.22(10)$
\end{tabular}

Numbers in parenthesis represent standard deviations. 
Table 2 Unit cell parameters of hydrous pyrope from powder X-ray diffraction data at various pressure-temperature conditions

\begin{tabular}{cccccc}
\hline $\mathrm{P}(\mathrm{GPa})$ & $\mathrm{T}(\mathrm{K})$ & $\mathrm{V}\left(\AA^{3}\right)$ & $\mathrm{P}(\mathrm{GPa})$ & $\mathrm{T}(\mathrm{K})$ & $\mathrm{V}\left(\AA^{3}\right)$ \\
\hline Compression before heating & & & $9.38(58)$ & 500 & $1438.79(83)$ \\
0.0 & 300 & $1505.53(64)$ & $11.28(66)$ & 500 & $1425.85(75)$ \\
$1.46(22)$ & 300 & $1492.13(76)$ & $13.44(54)$ & 500 & $1410.82(78)$ \\
$5.59(51)$ & 300 & $1457.56(86)$ & $15.26(62)$ & 500 & $1399.73(85)$ \\
$7.85(37)$ & 300 & $1441.26(82)$ & $2.46(54)$ & 700 & $1501.16(86)$ \\
$9.64(48)$ & 300 & $1428.62(85)$ & $4.52(59)$ & 700 & $1484.16(78)$ \\
Compression after heating & & & $6.77(33)$ & 700 & $1466.09(86)$ \\
$0.12(1)$ & 300 & $1504.28(92)$ & $8.45(45)$ & 700 & $1453.06(92)$ \\
$2.52(32)$ & 300 & $1482.26(85)$ & $10.28(52)$ & 700 & $1439.25(81)$ \\
$4.11(47)$ & 300 & $1469.09(84)$ & $12.49(54)$ & 700 & $1424.36(76)$ \\
$6.63(57)$ & 300 & $1449.75(74)$ & $14.55(63)$ & 700 & $1411.26(79)$ \\
$8.83(63)$ & 300 & $1434.26(87)$ & $16.03(47)$ & 700 & $1402.62(84)$ \\
$10.65(58)$ & 300 & $1422.08(84)$ & $2.98(56)$ & 900 & $1506.36(77)$ \\
$12.15(55)$ & 300 & $1411.87(88)$ & $5.33(46)$ & 900 & $1486.09(83)$ \\
$13.66(28)$ & 300 & $1402.09(75)$ & $7.42(58)$ & 900 & $1469.75(84)$ \\
$14.81(37)$ & 300 & $1395.10(92)$ & $9.37(52)$ & 900 & $1454.95(77)$ \\
$1.55(15)$ & 500 & $1500.13(86)$ & $10.79(45)$ & 900 & $1444.35(83)$ \\
$3.28(24)$ & 500 & $1484.66(83)$ & $13.21(36)$ & 900 & $1427.76(78)$ \\
$5.44(33)$ & 500 & $1467.09(87)$ & $15.44(45)$ & 900 & $1413.76(82)$ \\
$7.56(45)$ & 500 & $1450.83(76)$ & $16.75(64)$ & 900 & $1406.12(87)$ \\
\hline
\end{tabular}

Numbers in parenthesis represent standard deviations 
Table 3 Bulk modulus and its pressure derivative of dry pyrope and hydrous pyrope

\begin{tabular}{cccccc}
\hline Sample & $\mathrm{K}_{0}(\mathrm{GPa})$ & $\mathrm{K}_{0}^{\prime}$ & $\mathrm{V}_{0}\left(\AA^{3}\right)$ & Methods & Reference \\
\hline Hydrous Pyrope & $167(1)$ & $4.0^{\mathrm{a}}$ & $1505.04(29)$ & Powder-XRD & This study \\
Hydrous Pyrope & $161(2)$ & $5.0(3)$ & $1505.35(25)$ & Powder-XRD & This study \\
Hydrous Pyrope & $166(2)$ & $4.0^{\mathrm{a}}$ & $1504.58(32)$ & Single crystal-XRD & This study \\
Hydrous Pyrope & $160(3)$ & $5.2(4)$ & $1505.14(38)$ & Single crystal-XRD & This study \\
Dry Pyrope & 172.8 & $3.8(1)$ & 1503.87 & Powder-XRD & Leger et al. (1990) \\
Dry Pyrope & $169.2(2)$ & $4.4^{\mathrm{a}}$ & 1503.2 & Powder-XRD & Du et al. (2015) \\
Dry Pyrope & $175(1)$ & $4.5(5)$ & $1503.4(5)$ & Single crystal-XRD & Levien et al. (1979) \\
Dry Pyrope & $171(2)$ & $4.4(2)$ & $1502.9(3)$ & Single crystal-XRD & Zhang et al. (1998) \\
Dry Pyrope & $171.32(2)$ & 3.22 & - & BLS & Conrad et al. (1999) \\
Dry Pyrope & $171.2(20)$ & $4.1(3)$ & - & BLS & Sinogeikin and Bass (2000) \\
Dry Pyrope & $174.9(16)$ & $4.7(3)$ & - & BLS & Jiang et al. (2004) \\
Dry Pyrope & $171(2)$ & $5.3(4)$ & - & UI & Chen et al. (1999) \\
Dry Pyrope & $170.1(11)$ & $4.9(6)$ & - & UI & Wang and Ji (2001) \\
\hline
\end{tabular}

XRD, X-ray diffraction; BS, Brillouin Light Scattering; UI, Ultrosonic interferometry

Numbers in parenthesis represent standard deviations

${ }^{\text {a }}$ Fixed during fitting 
Table 4 Thermoelastic parameters of hydrous pyrope using the HTBM equation of state compared with dry pyrope

\begin{tabular}{ccccccc}
\hline Sample & $\mathrm{V}_{0}\left(\AA^{3}\right)$ & $\mathrm{K}_{0}(\mathrm{GPa})$ & $\mathrm{K}_{0}^{\prime}$ & $(\partial \mathrm{K} / \partial \mathrm{T})_{\mathrm{P}}\left(\mathrm{GPaK}^{-1}\right)$ & $\alpha_{0}\left(10^{-5} \mathrm{~K}^{-1}\right)$ & Reference \\
\hline Dry pyrope & $1503.1(5)$ & $170(2)$ & $5.0^{\mathrm{a}}$ & $-0.020(3)$ & $2.58(28)$ & Wang et al. (1998) \\
Dry pyrope & - & $169(2)$ & - & $-0.019(3)$ & - & Sinogeikin and Bass (2002) \\
Dry pyrope & 1502.5 & $172(4)$ & $3.9^{\mathrm{a}}$ & $-0.026(2)$ & - & Gwanmesia et al. (2006) \\
Dry pyrope & $1500.4(15)$ & $167(3)$ & $4.6^{\mathrm{a}}$ & $-0.021(9)$ & $2.89(33)$ & Zou et al. (2012) \\
Dry pyrope & $1502.8(4)$ & - & - & - & $2.74(5)$ & Du et al. (2015) \\
Hydrous pyrope & $1505.38(27)$ & $162(1)$ & $4.9(2)$ & $-0.018(4)$ & $3.19(10)$ & This study \\
Hydrous pyrope & $1505.22(28)$ & $168(1)$ & $4.0^{\mathrm{a}}$ & $-0.017(5)$ & $3.06(9)$ & This study \\
\hline
\end{tabular}

Numbers in parenthesis represent standard deviations

${ }^{\mathrm{a}}$ Fixed during fitting 


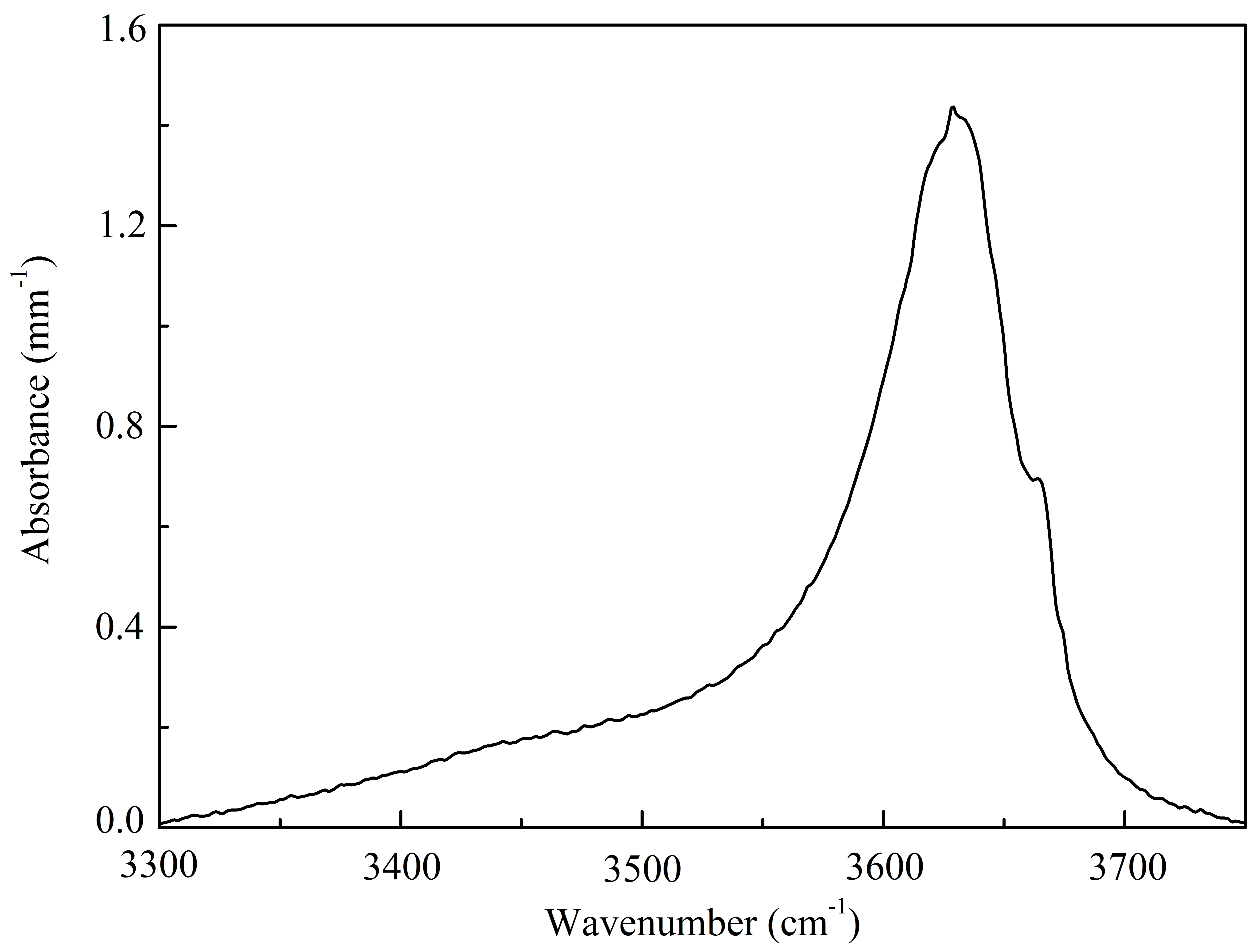




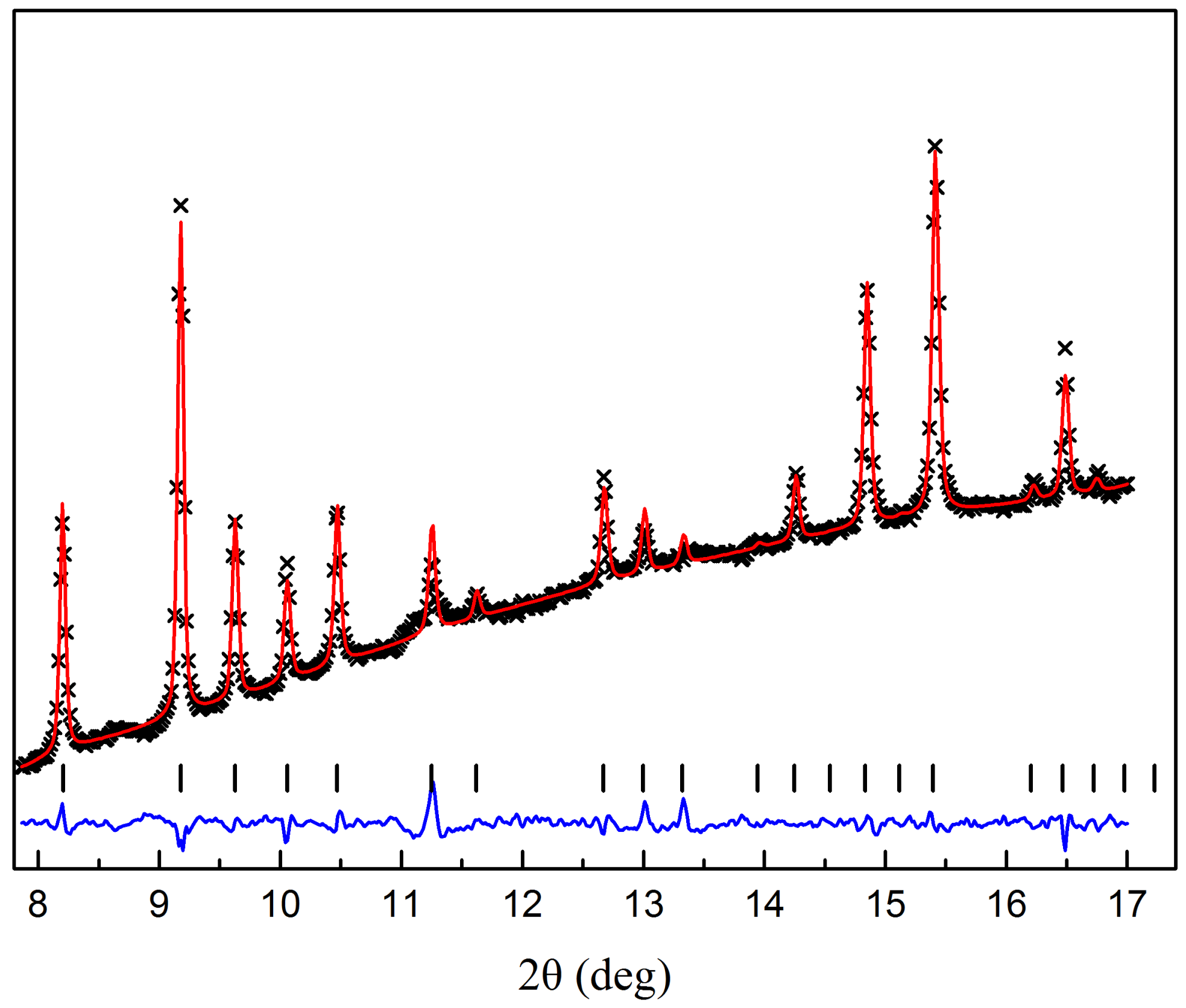




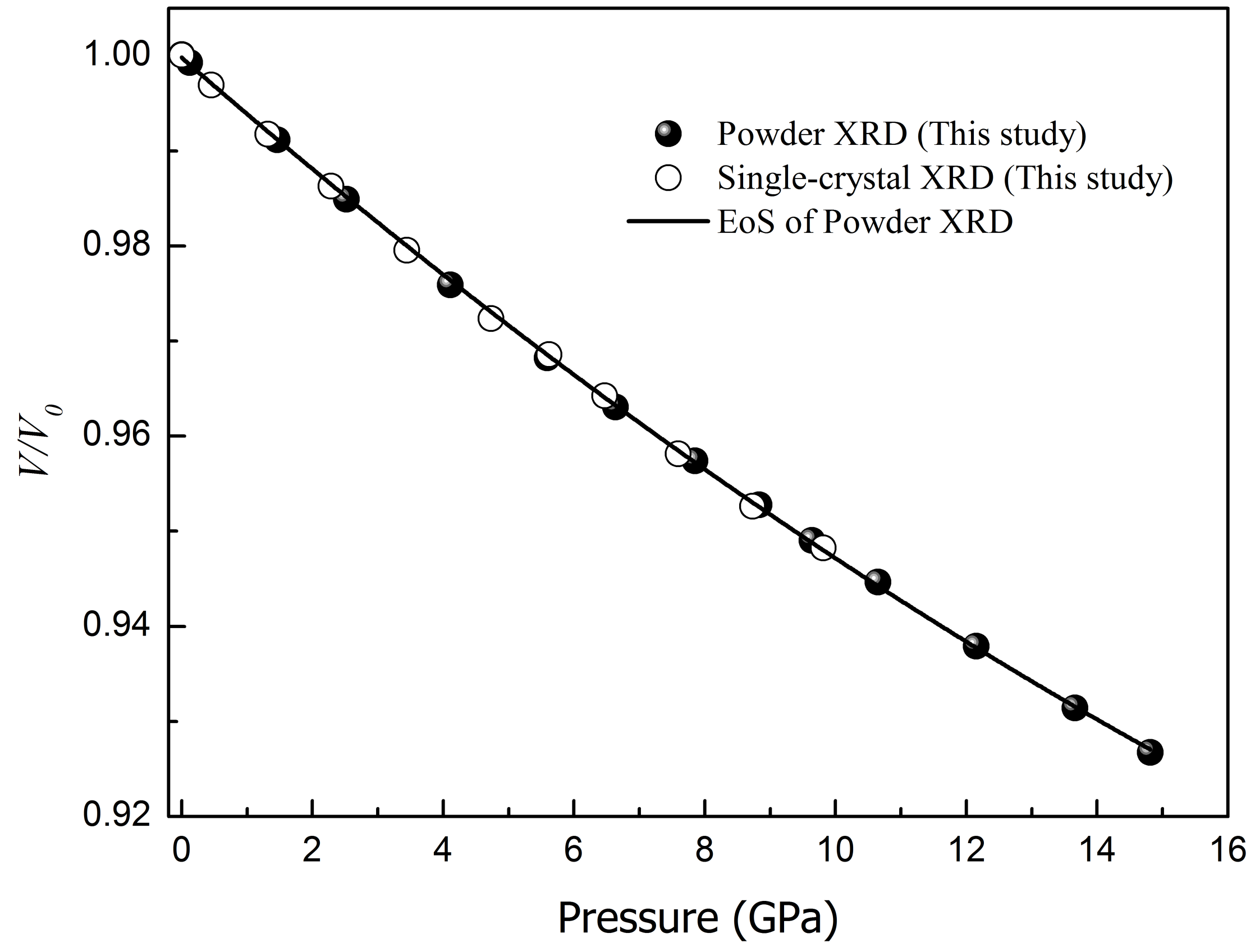




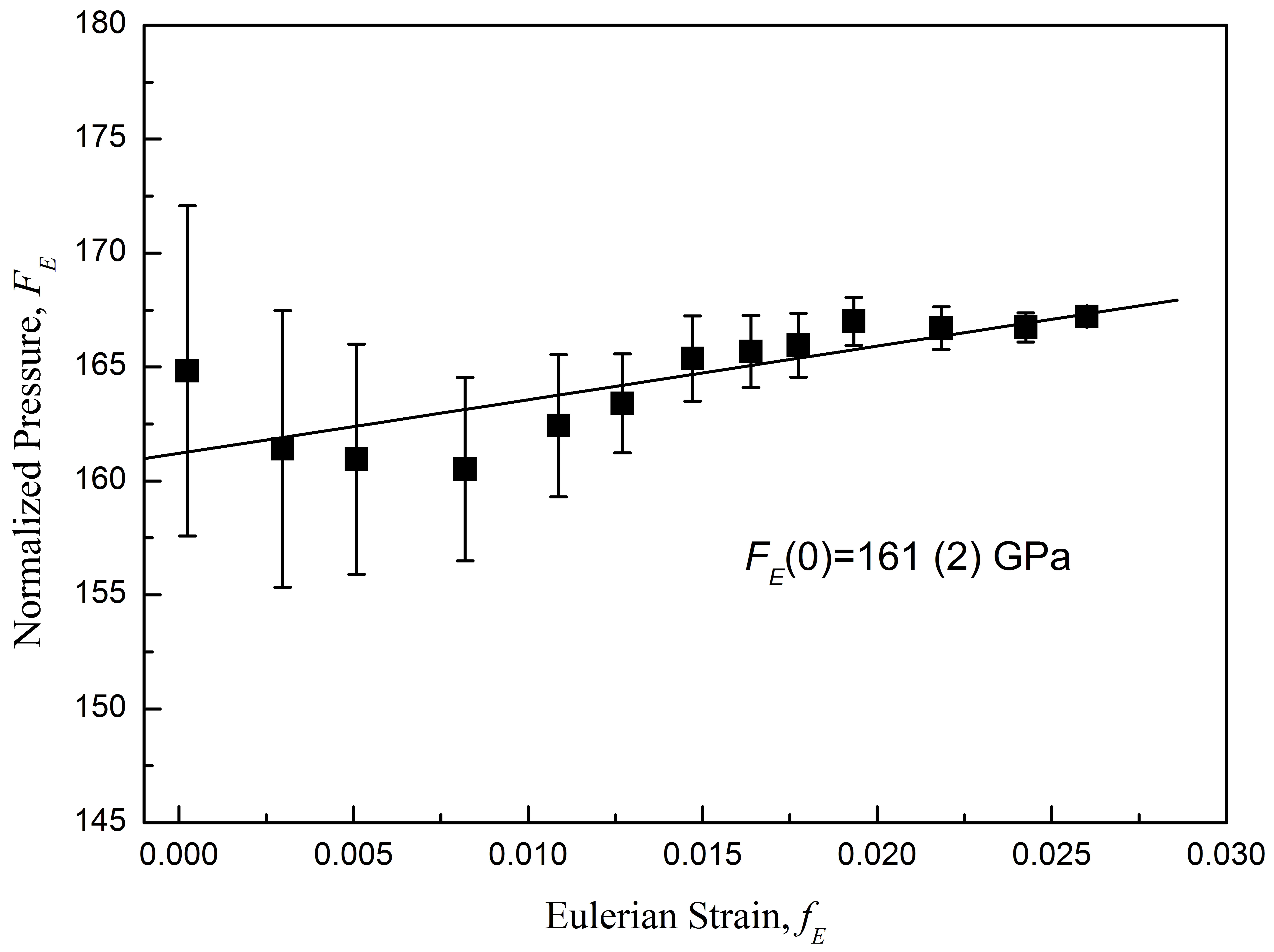




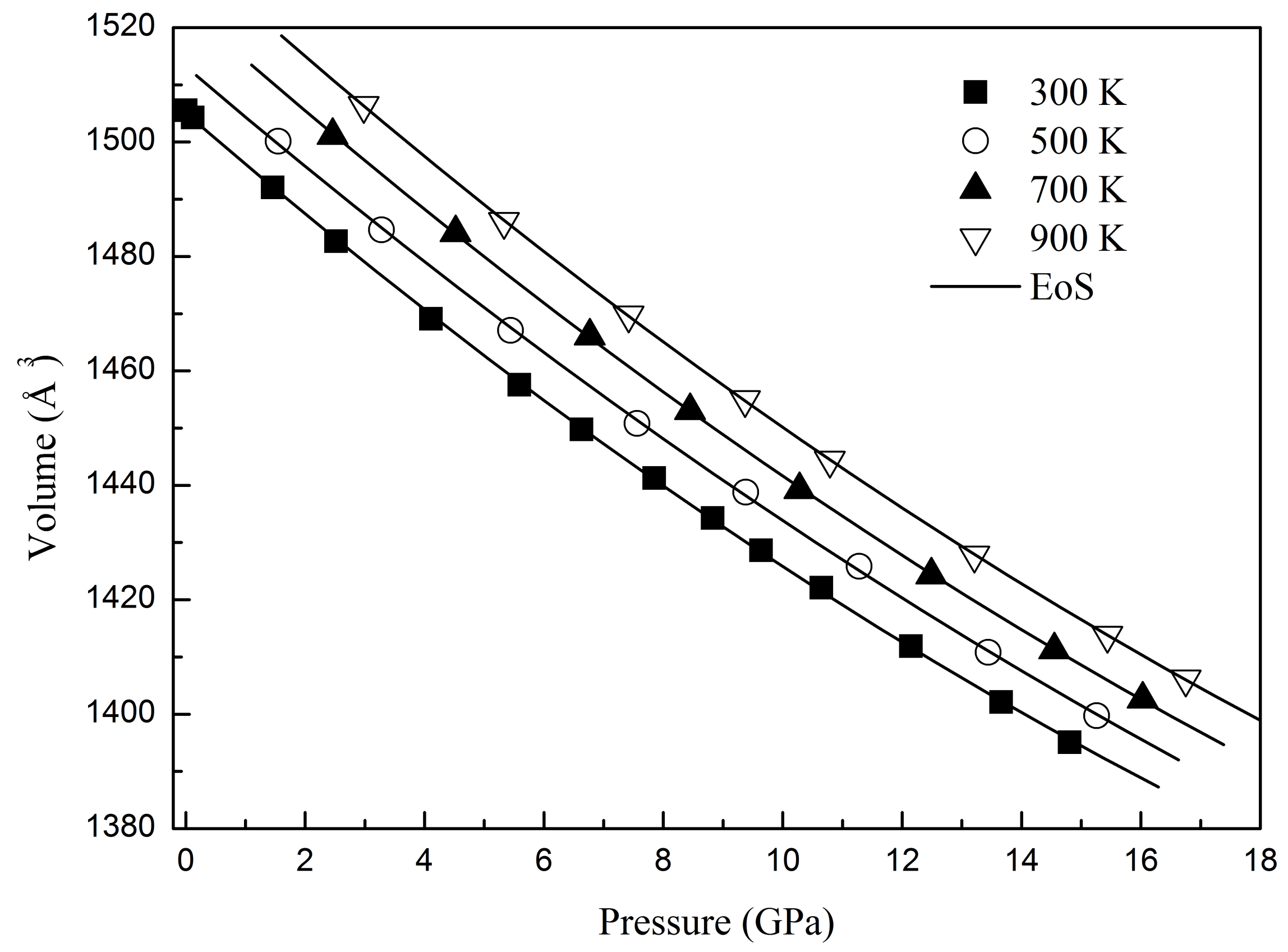




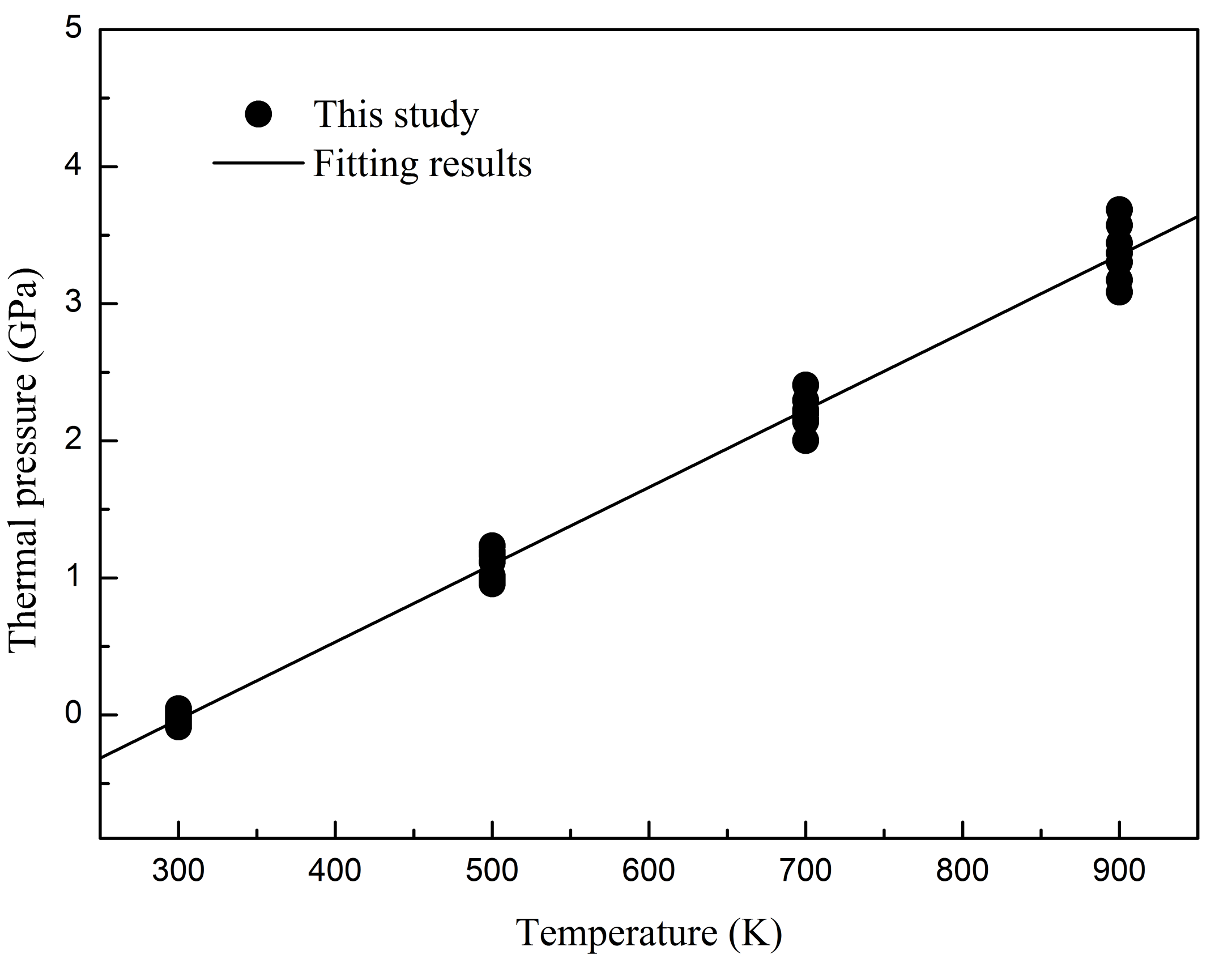




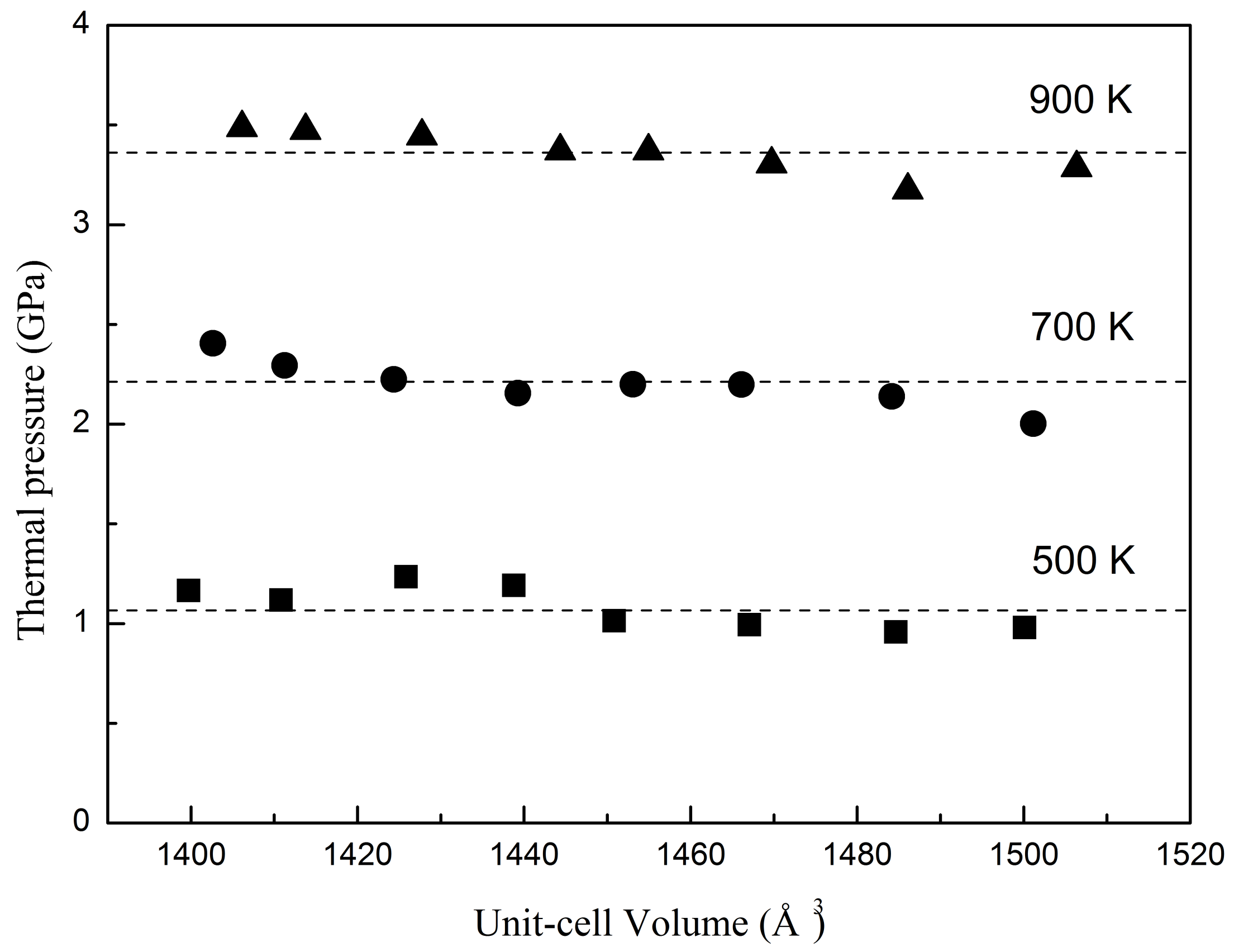




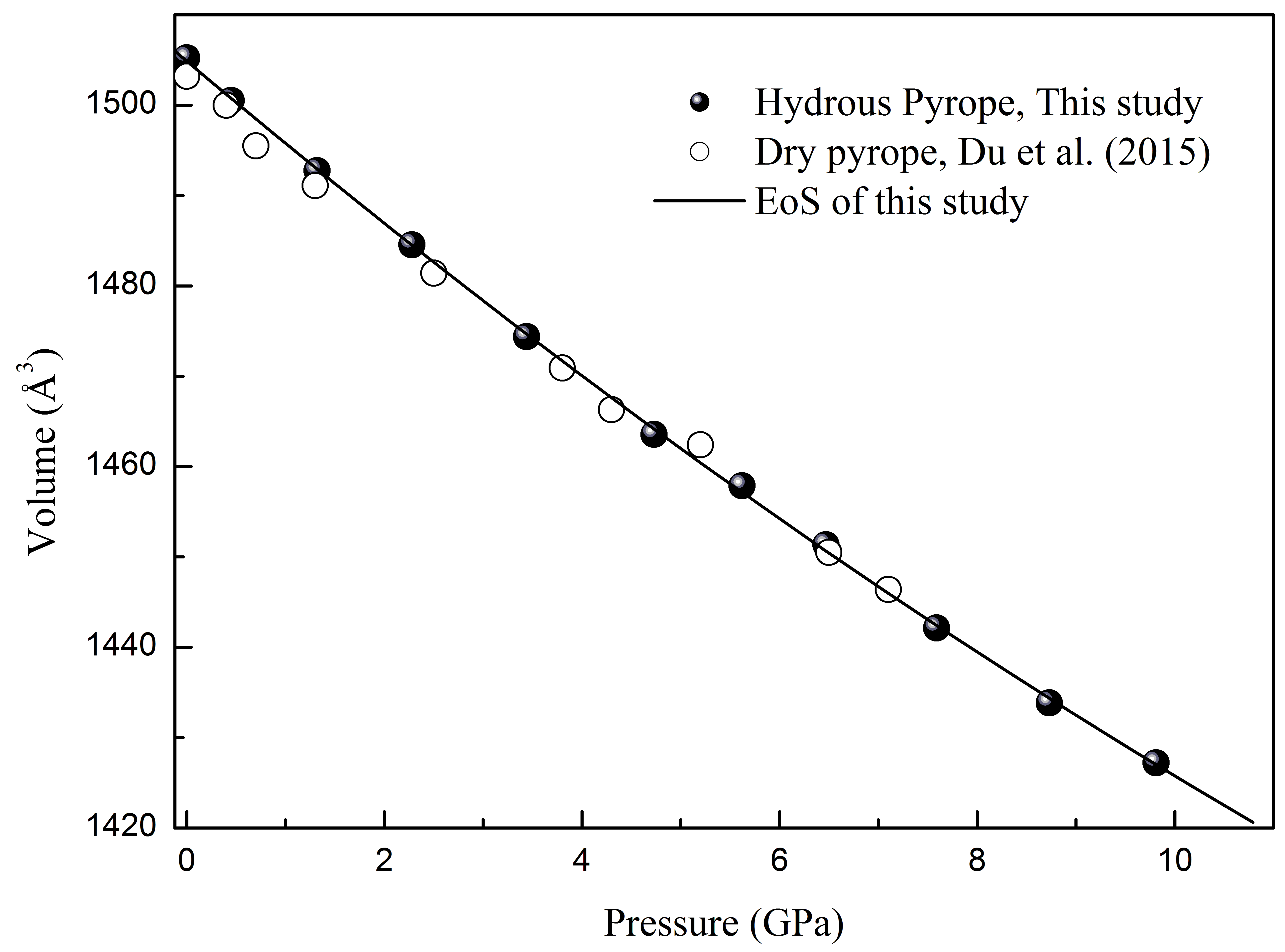




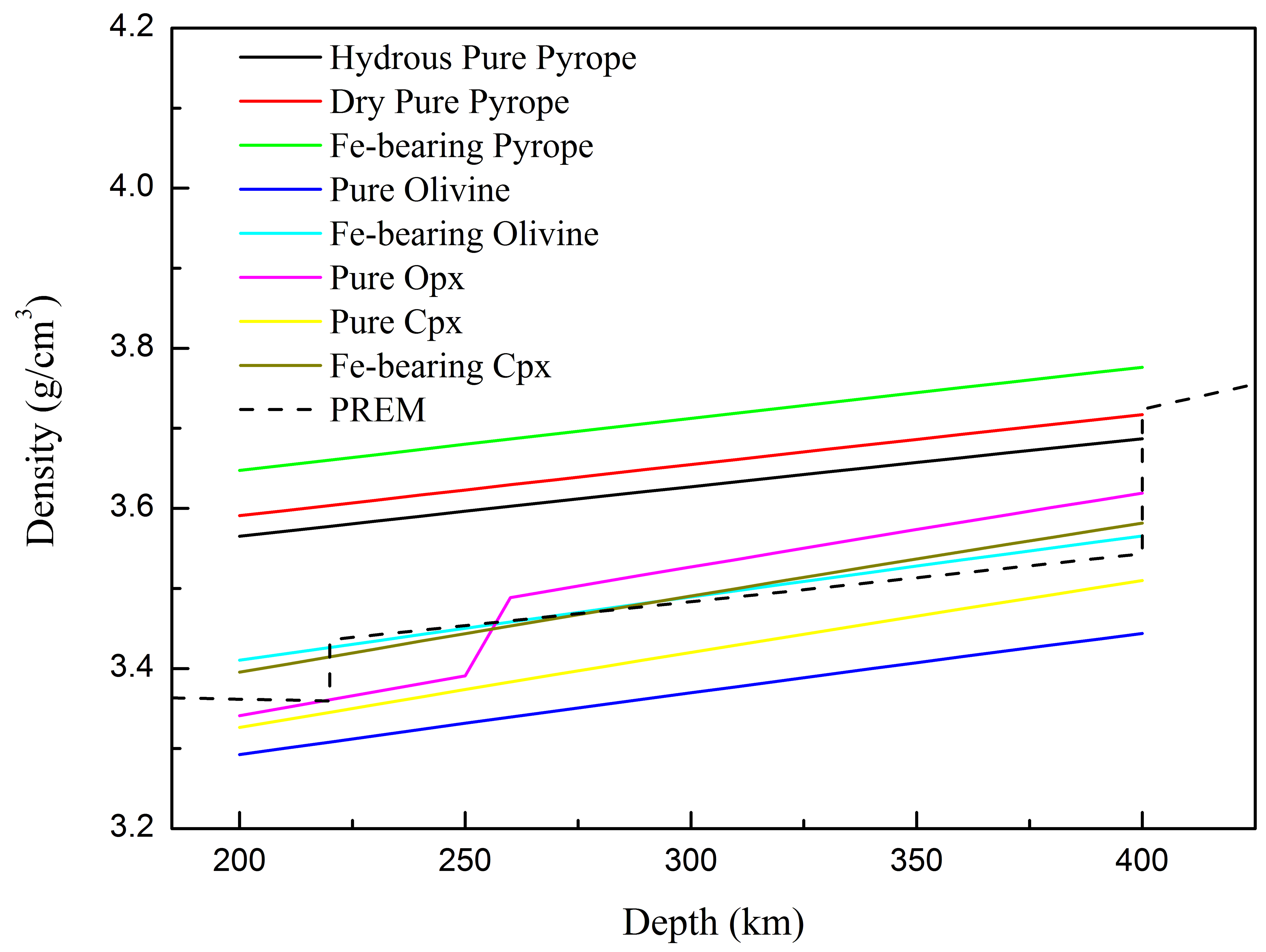




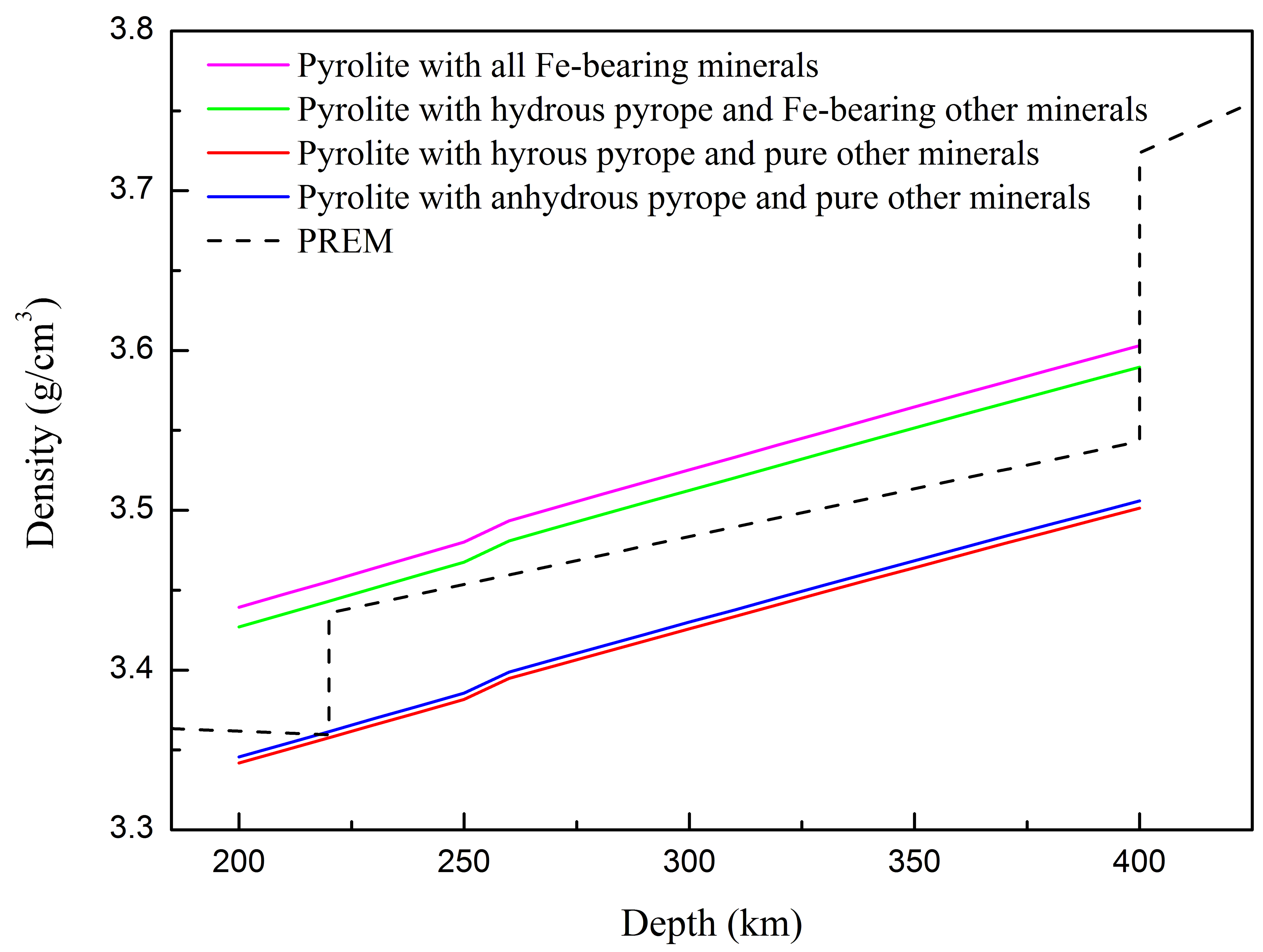

